\title{
Effects of Curcumin and Its Different Formulations in Preclinical and Clinical Studies of Peripheral Neuropathic and Postoperative Pain: A Comprehensive Review
}

\author{
Paramita Basu ${ }^{1}\left(\mathbb{D}_{\text {, Camelia Maier }}^{2}\left(\mathbb{D}\right.\right.$ and Arpita Basu ${ }^{3, *}$ \\ 1 Pittsburgh Center for Pain Research, and the Pittsburgh Project to End Opioid Misuse, \\ Department of Anesthesiology \& Perioperative Medicine, University of Pittsburgh School of Medicine, \\ Pittsburgh, PA 15213, USA; PAB171@pitt.edu \\ 2 Department of Biology, Texas Woman's University, Denton, TX 76204-5799, USA; cmaier@twu.edu \\ 3 Department of Kinesiology and Nutrition Sciences, School of Integrated Health Sciences, \\ University of Nevada, Las Vegas, NV 89154, USA \\ * Correspondence: Arpita.basu@unlv.edu; Tel.: +1-702-895-4576; Fax: +1-702-895-1500
}

Citation: Basu, P.; Maier, C.; Basu, A. Effects of Curcumin and Its Different Formulations in Preclinical and Clinical Studies of Peripheral Neuropathic and Postoperative Pain: A Comprehensive Review. Int. J. Mol. Sci. 2021, 22, 4666. https://doi.org/ $10.3390 /$ ijms 22094666

Academic Editor: Sara Marinelli

Received: 21 March 2021

Accepted: 26 April 2021

Published: 28 April 2021

Publisher's Note: MDPI stays neutral with regard to jurisdictional claims in published maps and institutional affiliations.

Copyright: (c) 2021 by the authors. Licensee MDPI, Basel, Switzerland. This article is an open access article distributed under the terms and conditions of the Creative Commons Attribution (CC BY) license (https:// creativecommons.org/licenses/by/ $4.0 /)$.

\begin{abstract}
Lesion or disease of the somatosensory system leads to the development of neuropathic pain. Peripheral neuropathic pain encompasses damage or injury of the peripheral nervous system. On the other hand, $10-15 \%$ of individuals suffer from acute postoperative pain followed by persistent pain after undergoing surgeries. Antidepressants, anticonvulsants, baclofen, and clonidine are used to treat peripheral neuropathy, whereas opioids are used to treat postoperative pain. The negative effects associated with these drugs emphasize the search for alternative therapeutics with better efficacy and fewer side effects. Curcumin, a polyphenol isolated from the roots of Curcuma longa, possesses antibacterial, antioxidant, and anti-inflammatory properties. Furthermore, the low bioavailability and fast metabolism of curcumin have led to the advent of various curcumin formulations. The present review provides a comprehensive analysis on the effects of curcumin and its formulations in preclinical and clinical studies of neuropathic and postoperative pain. Based on the positive outcomes from both preclinical and clinical studies, curcumin holds the promise of mitigating or preventing neuropathic and postoperative pain conditions. However, more clinical studies with improved curcumin formulations are required to involve its use as adjuvant to neuropathic and postoperative drugs.
\end{abstract}

Keywords: curcumin; curcumin formulations; diabetes; peripheral neuropathy; postoperative pain; preemptive analgesia

\section{Introduction}

Neuropathic pain has been defined as a process occurring after a primary lesion or the disease of the somatosensory nervous system [1]. Based on either clinical examination or self-reporting, the prevalence of neuropathic pain is $9.8 \%$ and $12.4 \%$, respectively, in the United States. However, due to differences in defining neuropathic pain, and employing different epidemiological assessment methods, it is difficult to provide the accurate estimate of neuropathic pain [2]. Peripheral neuropathic pain refers to damage or injury to the peripheral nerves [3]. According to the Special Interest Group on Neuropathic Pain, gabapentinoids, tricyclic antidepressants, and selective serotonin-norepinephrine reuptake inhibitors have been identified as the first-line drugs for neuropathic pain, whereas lidocaine, capsaicin, and tramadol are considered second-line drugs. Opioids such as morphine, oxycodone, and botulinum toxin-A are included as third-line treatments for peripheral neuropathic pain [4]. However, these drugs are accompanied by several side effects that limit their use in preventing or treating neuropathic pain [4].

On the other hand, acute postoperative pain is followed by persistent pain in 10-15\% individuals undergoing surgeries, such as breast, bypass, and thoracic surgery, coronary, 
groin hernia repair, and leg amputation [5]. Opioids are effectively used to treat postoperative pain [6]. However, prolonged use of opioids for chronic postoperative pain treatment is less efficacious and is associated with major side effects, such as addiction, dependence, liability, and opioid-induced hyperalgesia, nausea, vomiting, pruritus, and bowel motility reduction leading to ileus and constipation [7-10].

Taken together, the negative side effects associated with neuropathic and postoperative pain treatment reinforce the recommendations of evidence-based alternative therapeutics to treat these aforementioned pain conditions. Natural products, including herbals, flavonoids, and polyphenols, remain one of the most promising treatments for neuropathic [11-16] and postoperative pain $[17,18]$. Curcumin, also known as diferuloylmethane, is a polyphenolic compound present in the rhizomes of Curcuma longa (syn. C. domestica Valeton and C. brog Valeton) (Zingiberaceae) used as a culinary spice in curry powder [19]. The antioxidant and anti-inflammatory properties of curcumin $[20,21]$ could be attributed to its antinociceptive activity against different pain conditions, including peripheral neuropathic, inflammatory, postoperative, burn pain, and wound healing [22-25], as well as its use as an oral supplement in the treatment of various inflammatory medical conditions, such as alopecia [26].

Different curcumin formulations have been employed in order to improve the bioavailability mainly by providing protection against chemical degradation of curcumin [27-34]. These formulations include encapsulation technologies of curcumin into nanoparticles or microparticles and introduced in food or supplemental products [35]. Furthermore, the different colloidal particles that are used to incorporate curcumin include micellar aggregates, biopolymer particles, emulsion droplets, liposomes, and solid lipid particles [36].

The present review provides insights into the analgesic effects of curcumin and its formulations in neuropathic and postoperative pain conditions and explores its limitations in preclinical and clinical studies. To the best of our knowledge, this is the first comprehensive review that provides in-depth insights into the effects of curcumin and its different formulations on behavioral, electrophysiological, and molecular aspects of both peripheral neuropathic and postoperative pain.

\section{Materials and Methods}

The literature search mainly focused on the effects of curcumin and its different formulations on preclinical studies, especially in rodent models of peripheral neuropathic and postoperative pain conditions. However, a part of the review also presented the effects of curcumin and its formulations in clinical studies of neuropathic and postoperative pain. Outcome measures of interest were different behavioral modalities, such as mechanical, thermal (heat and cold), motor coordination, electrophysiological parameters, and molecular markers of antioxidative enzymes, reactive oxygen species (ROS), inflammation, and many more. All searches were conducted in PubMed and Google Scholar, and articles published between 2010 and 2021 were selected for the review. Key search terms were "curcumin", "curcumin formulations", "curcumin and peripheral neuropathic pain", "curcumin and postoperative pain", "curcumin bioavailability", "curcumin and neuropathic and clinical studies", and "curcumin and postoperative pain and clinical studies".

\section{Structure, Source, Metabolism, and Bioavailability of Curcumin}

\subsection{Chemical Structure}

Structurally, the chemical skeleton of curcumin [1,7-bis(4-hydroxy-3-methoxyphenyl)1,6-heptadiene-3,5-dione] possesses different functional moieties that are bonded to two phenol rings [37]. Two sets of $\alpha$ - and $\beta$-unsaturated carbonyl moieties link the phenol rings $[38,39]$, responsible for reaction with biological nucleophiles by employing Michael addition and C-C adducts [40,41]. Furthermore, the chemical structure of curcumin contains two methoxy aryl moieties at the ortho positions, a hydroxy substituent, and conjugated $\beta$-diketone moieties [41]. Curcumin exists in two different tautomeric forms: 1,3-diketo and enol forms [42,43] (Figure 1). 
Keto A<smiles>COc1cc(/C=C/C(=O)CC(=O)/C=C/c2ccc(O)c(OC)c2)ccc1O</smiles>

\section{Enol B}<smiles>COc1cc(/C=C/C(=O)CC(O)/C=C/c2ccc(O)c(OC)c2)ccc1O</smiles>

Figure 1. Keto A and enol B forms of curcumin.

\subsection{Source and Metabolism}

The genus Curcuma is widely cultivated in tropical and sub-tropical regions of Asia, Australia, and South America [44]. Curcumin is obtained from the tuberous rhizomes of C. longa, which is known as "turmeric" worldwide. C. longa is widely cultivated in India, China, and Indonesia $[19,45]$. The active components of Curcuma rhizomes involve volatile oils and nonvolatile curcuminoids (curcumin, demethoxycurcumin, bisdemethoxycurcumin), which are nontoxic polyphenolic derivatives with several biological activities $[46,47]$. Curcumin shows unfavorable pharmacokinetic properties (adsorption, distribution, excretion, and metabolism), insolubility in aqueous solutions, instability in neutral and alkaline $\mathrm{pH}$, as well as sensitivity of both solid and solubilized forms to light [48]. Curcumin metabolism mainly takes place in the liver, but also in the intestine by gut microbiota [49]. It is rapidly metabolized either through the phase II conjugation of curcumin-to-curcumin glucuronide and curcumin sulphate in the intestine and hepatic cytosol or phase I enzymatic reduction of curcumin to dihydrocurcumin, tetrahydrocurcumin, hexahydrocurcumin, and hexahydrocurcuminol in the enterocytes and hepatocytes [50-52]. Furthermore, glucuronidation occurs on reduced curcumin, leading to formation of curcumin glucuronide, dihydro-curcumin-glucuronide, tetrahydrocurcumin-glucuronide, and curcumin sulfate [50]. Dihydro-ferulic acid and ferulic acid are also formed as the products of secondary biliary metabolism $[53,54]$ (Figure 2).

\subsection{Bioavailability}

Table 1 summarizes the serum and tissue levels of curcumin in rodents and humans followed by different routes of administration. Despite its efficacy and safety, the poor bioavailability of curcumin undermines its therapeutic potential. Animal studies reported that oral administration $[55,56]$ of curcumin led to its poor absorption, rapid metabolism, and excretion. Oral consumption of curcumin leads to the rapid formation of conjugates, such as curcumin glucuronide and curcumin sulfate in the small intestine, liver, and kidneys. The conjugates undergo rapid excretion in the urine and feces [50,57-62]. In humans, curcumin has poor bioavailability, even when administered at a dose of $12 \mathrm{~g} /$ day [63]. Moreover, in humans, the oral bioavailability of curcumin is low because of its low absorption in the small intestine coupled to an extensive reduction and conjugation into metabolites in the liver followed by elimination through the gall bladder $[54,64]$. 

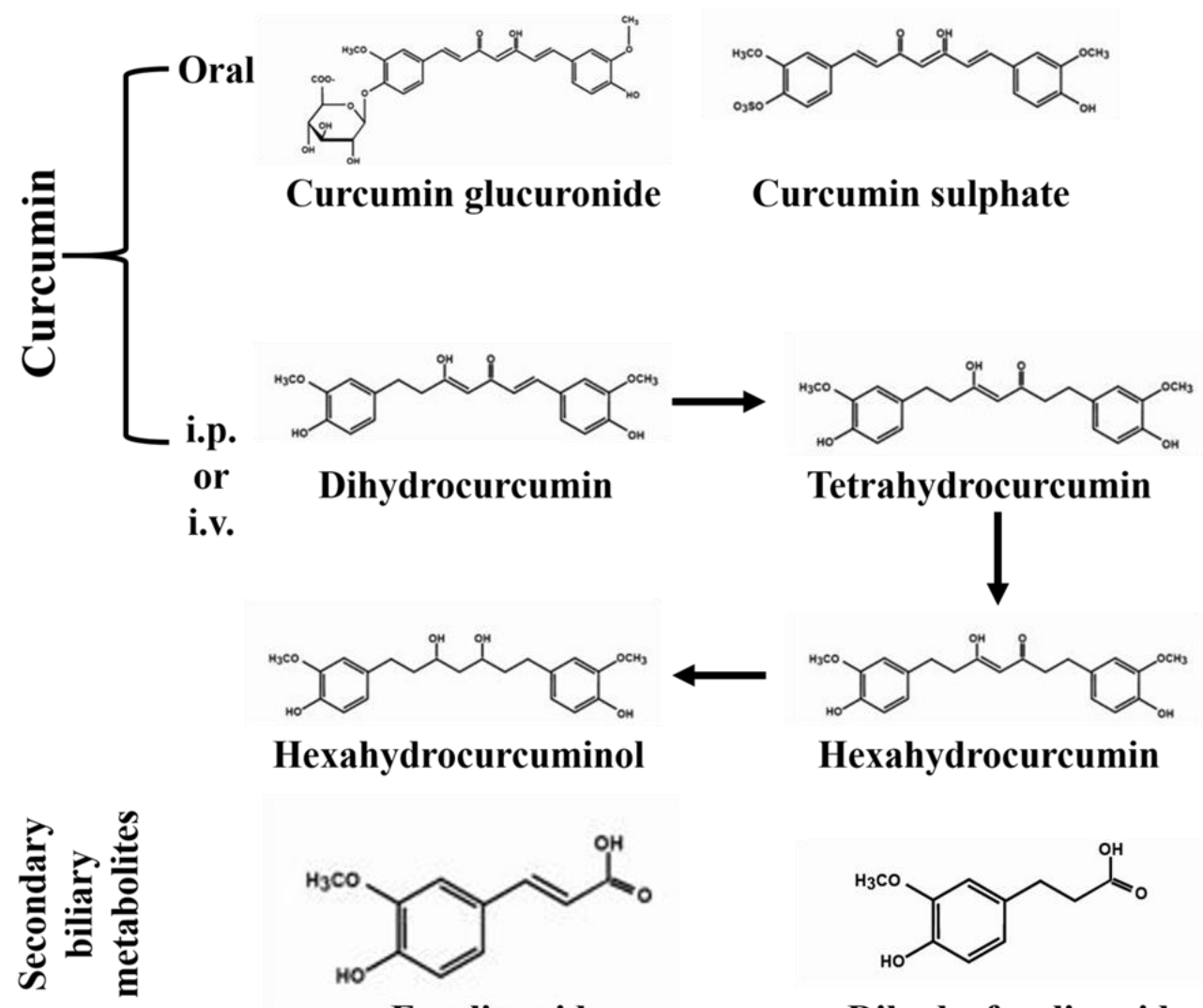

Hexahydrocurcuminol<smiles>COc1cc(/C=C/C(=O)O)ccc1O</smiles>

Ferulic acid<smiles>Cc1ccc(CCC(O)O)cc1O</smiles>

Dihydroferulic acid

Figure 2. Structures of curcumin metabolites following oral or intraperitoneal (i.p.) or intravenous (i.v.) administration. 
Table 1. Serum and tissue levels of curcumin in animal and clinical studies.

\begin{tabular}{|c|c|c|c|c|c|}
\hline \multirow[b]{2}{*}{ Animals } & \multirow[b]{2}{*}{ Dose $^{a}$, Route of Administration } & \multicolumn{3}{|c|}{ Bioavailability } & \multirow[b]{2}{*}{ Reference } \\
\hline & & Tissue & Concentration & $\begin{array}{l}\text { Time Measured after } \\
\text { Administration }\end{array}$ & \\
\hline \multicolumn{6}{|c|}{ Animal Studies } \\
\hline \multirow[t]{2}{*}{ NMRI and C57/BL6 mouse } & $50 \mathrm{mg} / \mathrm{kg}$, force-fed & Brain & Below detection limit & 30,60 , and $120 \mathrm{~min}$ & \\
\hline & 100 mg/kg, i.p. & & $0.004-0.005 \mathrm{mg} / \mathrm{g}$ & $20-40 \mathrm{~min}$ & [65] \\
\hline \multirow[t]{5}{*}{$\begin{array}{l}\text { C57BL6/J male and female } \\
\text { mice }\end{array}$} & 0.148 mg, i.p. & $\begin{array}{c}\text { Brain } \\
\text { Plasma }\end{array}$ & $\begin{array}{c}0.000739 \pm 0.019 \mathrm{mg} / \mathrm{g} \\
2.010 \mu \mathrm{M} \\
0.000127 \pm 0.035 \mathrm{mg} / \mathrm{mL} \\
0.345 \mu \mathrm{M}\end{array}$ & $4 \mathrm{~h}$ & [55] \\
\hline & $0.148 \mathrm{mg}$, oral & $\begin{array}{c}\text { Brain } \\
\text { Plasma }\end{array}$ & $\begin{array}{c}0.000519 \pm 0.098 \mathrm{a} \mathrm{mg} / \mathrm{g} \\
1.412 \mu \mathrm{M} \\
\text { Below detection level }\end{array}$ & $4 \mathrm{~h}$ & \\
\hline & $0.074 \mathrm{mg}$, intramuscular & $\begin{array}{l}\text { Brain } \\
\text { Plasma }\end{array}$ & $\begin{array}{c}0.001162 \pm 0.004 \mathrm{mg} / \mathrm{g} \\
3.157 \mu \mathrm{M} \\
0.000238 \pm 0.048 \mathrm{mg} / \mathrm{mL} \\
0.647 \mu \mathrm{M}\end{array}$ & $4 \mathrm{~h}$ & \\
\hline & $\sim 2.5 \mathrm{mg} /$ day, oral (500 ppm) & $\begin{array}{l}\text { Brain } \\
\text { Plasma }\end{array}$ & $\begin{array}{c}0.000469 \pm 0.220 \mathrm{mg} / \mathrm{g} \\
1.276 \mu \mathrm{M} \\
0.000035 \pm 0.014 \mathrm{mg} / \mathrm{mL} \\
0.095 \mu \mathrm{M}\end{array}$ & 4 months & \\
\hline & 10 mg/day, oral (2000 ppm) & $\begin{array}{c}\text { Brain } \\
\text { Plasma }\end{array}$ & $\begin{array}{c}0.000525 \pm 0.125 \mathrm{mg} / \mathrm{g} \\
1.428 \mu \mathrm{M} \\
0.000171 \pm 0.019 \mathrm{mg} / \mathrm{mL} \\
0.465 \mu \mathrm{M}\end{array}$ & 4 months & \\
\hline \multirow[t]{2}{*}{ Male Sprague-Dawley rats } & $500 \mathrm{mg} / \mathrm{kg}$, oral & Plasma & $0.00006 \pm 0.01 \mathrm{mg} / \mathrm{mL}$ & $41.7 \pm 5.4 \mathrm{~min}$ & {$[56]$} \\
\hline & $10 \mathrm{mg} / \mathrm{kg}$, intravenous & Plasma & $0.00036 \pm 0.05 \mathrm{mg} / \mathrm{mL}$ & Not mentioned & \\
\hline Male Sprague-Dawley rats & $1000 \mathrm{mg} / \mathrm{kg}$, oral & Plasma & $15 \mathrm{ng} / \mathrm{mL}$ & $50 \mathrm{~min}$ & {$[66]$} \\
\hline Female BALB/c mice & $0.1 \mathrm{~g} / \mathrm{kg}$, i.p. & $\begin{array}{l}\text { Brain } \\
\text { Intestine } \\
\text { Kidneys } \\
\text { Liver } \\
\text { Plasma } \\
\text { Spleen }\end{array}$ & $\begin{array}{c}0.00041 \pm 0.01 \mathrm{mg} / \mathrm{g} \\
0.11704 \pm 6.86 \mathrm{mg} / \mathrm{g} \\
0.00751 \pm 0.08 \mathrm{mg} / \mathrm{g} \\
0.0269 \pm 2.58 \mathrm{mg} / \mathrm{g} \\
0.0006 \pm 0.03 \mathrm{mg} / \mathrm{g} \\
0.02606 \pm 1.06 \mathrm{mg} / \mathrm{g}\end{array}$ & $1 \mathrm{~h}$ & {$[50]$} \\
\hline
\end{tabular}


Table 1. Cont.

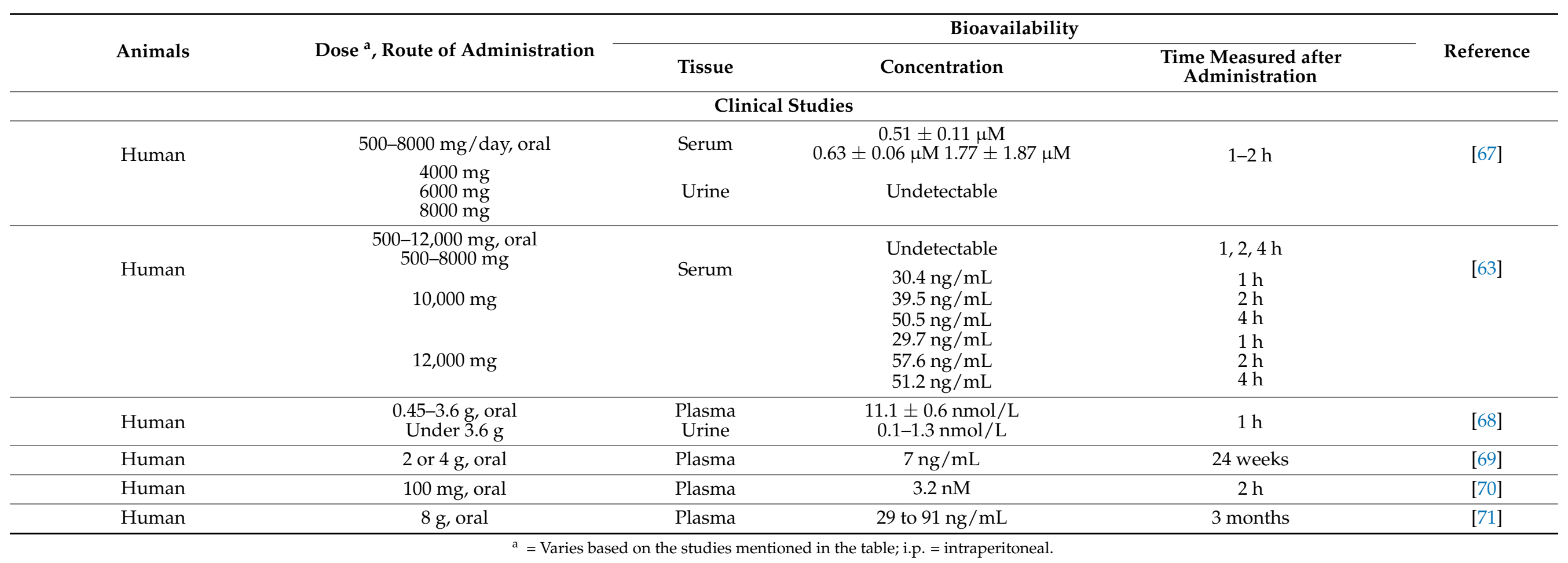




\section{Curcumin and Neuropathic Pain-Preclinical Studies}

\subsection{Alcoholic Neuropathy}

Chronic alcohol consumption leads to an array of neurological aberrations, including cortical and motility dysfunction, delirium tremens, psychosis, peripheral polyneuropathy, and Wernicke encephalopathy [72]. Direct toxicity to alcohol, family history of alcoholism, malnutrition, and thiamine deficiency are associated with alcoholic neuropathy [73-76]. However, it is unclear which of the above factors induces neuropathy [77]. Moreover, alcohol promotes oxidative stress by decreasing the endogenous concentrations of antioxidants, such as $\alpha$-tocopherol, ascorbate, and vitamin E [78], generating ROS and lipid peroxidation [79], and damaging DNA, cellular protein, and other signaling pathways that regulate oxidative stress [78].

Table 2 summarizes the effects of curcumin on alcoholic neuropathy. Curcumin reduced alcohol-induced mechanical and thermal (heat and cold) hypersensitivity, inhibited the reduction in motor nerve conduction velocity (MNCV), reduced inflammatory cytokines, such as tumor necrosis factor alpha (TNF- $\alpha$ ) and interleukin-1 $\beta$ (IL-1 $\beta$ ), and reduced DNA fragmentation [80]. Curcumin also exerts antioxidant properties by reducing the levels of calcium, neural nitrite, and malondialdehyde (MDA), and restoring glutathione (GSH) levels [80]. Curcumin has also revealed better efficacy in reducing the alcohol-induced behavioral outcomes and inflammatory cytokines when compared to the standard drug $\alpha$-tocopherol [80]. Treatments with curcumin or sildenafil, a drug that is reported to reduce neuropathic pain in rodent models [81,82], did not reduce the alcohol-induced pain behaviors and did not alter oxidative stress biomarkers [83]. However, combined low doses of curcumin and sildenafil were effective in treating chronic alcohol-induced neuropathic pain. The results confirm that low doses of curcumin and sildenafil might have interacted synergistically to mitigate alcoholic neuropathy [83]. Therefore, the drug-supplement association might provide a therapeutic advantage in treating alcoholic neuropathy under clinical settings. 
Table 2. Effects of curcumin on alcoholic neuropathy, chemotherapy-induced peripheral neuropathy (CIPN), and diabetic painful neuropathy (DPN).

\begin{tabular}{|c|c|c|c|c|c|}
\hline \multirow[b]{2}{*}{ Animals (Sex, Strain) } & \multirow[b]{2}{*}{ Dose (mg/kg), Route of Administration, Duration of Treatment } & \multicolumn{3}{|c|}{ Effects } & \multirow[b]{2}{*}{ Reference } \\
\hline & & Behavioral/Other & $\begin{array}{l}\text { Electrophysiological/ } \\
\text { Functional }\end{array}$ & $\begin{array}{l}\text { Histopathological/ } \\
\text { Biochemical/Molecular }\end{array}$ & \\
\hline \multicolumn{6}{|c|}{ Alcoholic Neuropathy } \\
\hline Male Wistar rats & $\begin{array}{c}35 \%(v / v) \text { ethanol } 10 \mathrm{~g} / \mathrm{kg} \text {, b.i.d (bis in die, i.e., twice daily), oral, } \\
10 \text { weeks }+ \text { curcumin: } 20,40 \text { and } 80 \mathrm{mg} / \mathrm{kg} \text {, oral, } 10 \text { weeks }+35 \% \\
(v / v) \text { ethanol }(10 \mathrm{~g} / \mathrm{kg}) \text {, oral, } 10 \text { weeks }\end{array}$ & $\begin{array}{c}\uparrow \text { Mechanical hyperalgesia threshold } \\
\text { (Randall-Selitto paw pressure test) } \\
\downarrow \text { Mechanical allodynia (von Frey hair test) } \\
\text { Thermal hyperalgesia (Tail immersion test) }\end{array}$ & $\begin{array}{l}\mathrm{X} \text { Reduction in } \\
\text { MNCV }\end{array}$ & $\begin{array}{c}\downarrow \mathrm{MDA} \text {, neural nitrite, and total calcium content } \\
\quad \downarrow \text { TNF- } \alpha \text { and IL-1 } \beta \\
\text { and DNA fragmentation in sciatic nerve }\end{array}$ & [80] \\
\hline \multicolumn{6}{|c|}{ Combination Study } \\
\hline $\begin{array}{l}\text { Wistar Albino rats of } \\
\text { either sex }\end{array}$ & 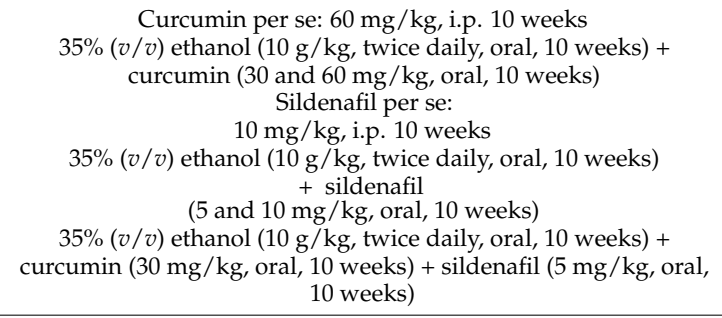 & $\begin{array}{c}\text { Combination } \checkmark \text { Improved motor coordination } \\
\text { (rotarod test) } \\
\downarrow \text { Thermal hyperalgesia (hotplate test) and paw } \\
\text { heat allodynia (hotplate test), mechanical } \\
\text { hyperalgesia (pin prick test), cold allodynia } \\
\text { (acetone test), tail cold-hyperalgesia (tail } \\
\text { immersion test) }\end{array}$ & Not tested & $\begin{array}{c}\downarrow \text { MDA level } \\
\checkmark \text { GSH level } \\
\downarrow \text { Ethanol-induced fiber derangement, nerve fiber } \\
\text { swelling, Schwann cells activation } \\
\checkmark \text { Nerve fibers }\end{array}$ & [83] \\
\hline \multicolumn{6}{|c|}{ Chemotherapy-Induced Peripheral Neuropathy (CIPN) } \\
\hline Male Sprague-Dawley rats & $\begin{array}{c}\text { Paclitaxel }(2 \mathrm{mg} / \mathrm{kg} \text {, i.p., } 5 \text { consecutive days) } \\
\text { Curcumin }(200 \mathrm{mg} / \mathrm{kg} / \text { day, oral, } 10 \text { consecutive days) } \\
\text { Paclitaxel }(2 \mathrm{mg} / \mathrm{kg}, \mathrm{i} \text {. p., } 5 \text { consecutive days })+\text { curcumin }(100 \text { or } \\
200 \mathrm{mg} / \mathrm{kg} / \text { day, oral, } 10 \text { consecutive days })\end{array}$ & Not tested & Not tested & $\begin{array}{c}\text { In spinal cord and sciatic nerve tissues: } \\
\downarrow \text { NF- } \kappa \text { B and GFAP levels } \\
\downarrow \text { mRNA expressions of TNF- } \alpha \text {, IL6, NF- } \kappa B \text {, iNOS, } \\
\text { Bcl-2 and Bcl-xL } \\
\uparrow \text { mRNA expression of Nrf2 } \\
\downarrow \text { mRNA expressions of caspase-3, p53, Apaf-1 } \\
\downarrow \text { mRNA expressions of autophagy related genes } \\
\text { LC3A, LC3B, and Beclin-1 } \\
\downarrow \text { Immunohistochemical expressions of 8-OHdG, } \\
\text { caspase-3 and LC3B } \\
\checkmark \text { Spinal cord and sciatic nerve histological } \\
\text { architecture and integrity with no sciatic nerve } \\
\text { damage, including vacuolation, neuronal } \\
\text { degeneration, and demyelination }\end{array}$ & [84] \\
\hline $\begin{array}{c}\text { Male } \\
\text { Sprague-Dawley rats }\end{array}$ & $\begin{array}{l}\text { Oxaliplatin (4 mg/kg, i.p., twice weekly for } 4 \text { weeks) + curcumin } \\
(12.5,25 \text { and } 50 \mathrm{mg} / \mathrm{kg} \text {, oral, } 4 \text { weeks })\end{array}$ & $\begin{array}{c}\uparrow \text { Mechanical (von Frey) threshold } \\
\downarrow \text { Cold allodynia (acetone test) }\end{array}$ & $\underset{\mathrm{SNCV}}{\mathrm{MNCV} \text { and }}$ & $\begin{array}{c}\checkmark \text { Injured spinal cord cells } \\
\uparrow \text { Levels of SOD, GSH-Px, and CAT in spinal cord } \\
\downarrow \text { MDA level in spinal cord } \\
\text { X Protein expression of p-NF- } \mathrm{kB} / \mathrm{NF}-\mathrm{kB} \text { in spinal } \\
\quad \text { cord } \\
\downarrow \text { TNF- } \alpha, \text { IL- } 6 \text { and IL- } 1 \beta \text { levels in spinal cord }\end{array}$ & [85] \\
\hline Female Wistar rats & $\begin{array}{l}\text { Cisplatin }(2 \mathrm{mg} / \mathrm{kg} \text {, i.p., twice a week for } 5 \text { weeks })+ \\
\text { curcumin }(200 \mathrm{mg} / \mathrm{kg} \text {, oral, once daily for } 5 \text { weeks })\end{array}$ & $\downarrow$ Thermal hypoalgesia (hotplate test) & $\begin{array}{l}\checkmark \text { Reduction in } \\
\text { MNCV }\end{array}$ & $\begin{array}{l}\uparrow \text { Myelin thickness in sciatic nerve } \\
\text { X Nuclear and nucleolar atrophy, loss of neurons in } \\
\text { L4 DRG }\end{array}$ & [86] \\
\hline
\end{tabular}


Table 2. Cont.

\begin{tabular}{|c|c|c|c|c|c|}
\hline \multirow[b]{2}{*}{ Animals (Sex, Strain) } & \multirow[b]{2}{*}{ Dose $(\mathrm{mg} / \mathrm{kg})$, Route of Administration, Duration of Treatment } & \multicolumn{3}{|c|}{ Effects } & \multirow[b]{2}{*}{ Reference } \\
\hline & & Behavioral/Other & $\begin{array}{l}\text { Electrophysiological/ } \\
\text { Functional }\end{array}$ & $\begin{array}{c}\text { Histopathological/ } \\
\text { Biochemical/Molecular }\end{array}$ & \\
\hline \multicolumn{6}{|c|}{ Chemotherapy-Induced Peripheral Neuropathy (CIPN) } \\
\hline Male Swiss Albino mice & $\begin{array}{c}\text { Vincristine sulfate }(0.1 \mathrm{mg} / \mathrm{kg}, \text { i.p., once per day for } \\
7 \text { consecutive days })+ \text { curcumin }(15,30,60 \mathrm{mg} / \mathrm{kg} / \text { day, oral, } \\
14 \text { consecutive days })\end{array}$ & $\begin{array}{c}\uparrow \text { Thermal hyperalgesia (hotplate test) } \\
\downarrow \text { Thermal allodynia (cold plate test) and } \\
\text { mechanical hyperalgesia (pin prick test) } \\
\text { O Motor coordination (rotarod test) } \\
\text { O Acute phase of nociception (formalin test) } \\
\downarrow \text { Paw elevation and licking in delayed phase of } \\
\text { nociception (formalin test) }\end{array}$ & $\begin{array}{l}\downarrow \text { Vincristine- } \\
\text { induced rise in } \\
\text { SFI }\end{array}$ & $\begin{array}{c}\downarrow \text { Calcium level in sciatic nerve } \\
\uparrow \text { SOD activity in sciatic nerve } \\
\uparrow \text { Sciatic SOD, CAT, GPx, and GSH } \\
\quad \downarrow \text { Levels of LPO and NO }\end{array}$ & [87] \\
\hline \multicolumn{6}{|c|}{ Diabetic Painful Neuropathy (DPN) } \\
\hline \multirow[t]{2}{*}{ Male Wistar rats } & \multirow[t]{2}{*}{$\begin{array}{c}\text { Streptozotocin (STZ) } \begin{array}{c}(100 \mathrm{mg} / \mathrm{kg} \text {, i.p. })+\text { curcumin }(100 \mathrm{mg} / \mathrm{kg} \text {, } \\
\text { oral, } 6 \text { weeks })\end{array}\end{array}$} & \multirow[t]{2}{*}{$\begin{array}{l}\uparrow \text { Body weight, and kidney weight/body weight } \\
\uparrow \text { Thermal hyperalgesia (hotplate and tail flick } \\
\text { test) and mechanical allodynia (von Frey) }\end{array}$} & & $\begin{array}{c}\downarrow \text { FBG, TG, total cholesterol, LDL-C, total peroxide, } \\
\text { serum creatinine, and BUN } \\
\uparrow \text { HDL-C } \\
\downarrow \text { Renal ACE1 }\end{array}$ & \multirow[t]{2}{*}{ [89] } \\
\hline & & & & $\checkmark$ TNF- $\alpha$ and IL-10 in kidneys and sciatic nerves & \\
\hline Male Albino Wistar rats & $\begin{array}{l}\text { STZ }(60 \mathrm{mg} / \mathrm{kg} \text {, i.p. })+\text { acute or chronic curcumin } \\
\text { (50 mg/kg/day, i.p.) } \\
\text { Acute treatment: only } 30 \mathrm{~min} \text { prior to pain assessment } \\
\text { Chronic treatment: from } 7 \text { th day till } 21 \mathrm{st} \text { day injected once a day }\end{array}$ & $\begin{array}{c}\text { O Hyperglycemia } \\
\text { Chronic treatment } \mathbf{X} \text { Weight loss } \\
\text { Chronic treatment } \uparrow \text { Thermal hyperalgesia } \\
\text { (plantar test) and mechanical allodynia (von Frey) } \\
\text { Naloxone pre-treatment } \downarrow \text { Anti-allodynic effect of } \\
\text { chronic curcumin }\end{array}$ & Not tested & Not tested & [91] \\
\hline Male Sprague-Dawley rats & STZ $(60 \mathrm{mg} / \mathrm{kg}$, i.p. $)+\underset{14 \text { days })}{\text { curcumin }}(200 \mathrm{mg} / \mathrm{kg}$, intragastric, & $\begin{array}{c}\text { O Hyperglycemia and increased body weight } \\
\uparrow \text { Tactile allodynia (von Frey) }\end{array}$ & Not tested & $\begin{array}{c}\checkmark \text { Protein expressions of NADPH oxidase subunits } \\
\text { gp9 } 91^{\text {phox }} \text { and p47phox in spinal cord } \\
\downarrow \mathrm{H}_{2} \mathrm{O}_{2} \text { and MDA in spinal cord } \\
\uparrow \text { SOD in spinal cord }\end{array}$ & [92] \\
\hline $\begin{array}{c}\text { Male } \\
\text { Sprague-Dawley rats }\end{array}$ & $\begin{array}{l}\text { STZ }(65 \mathrm{mg} / \mathrm{kg} \text {, i.p. })+\underset{\text { curcumin }(60 \mathrm{mg} / \mathrm{kg} \text {, oral, daily from day }}{3 \text { to day } 28)}\end{array}$ & $\begin{array}{c}\downarrow \text { Hyperglycemia and body weight } \\
\checkmark \text { Thermal hyperalgesia (Hargreaves test) and } \\
\text { mechanical allodynia (von Frey) }\end{array}$ & Not tested & $\downarrow$ Spinal TNF- $\alpha$ and TNF- $\alpha$ receptor 1 & [93] \\
\hline
\end{tabular}


Table 2. Cont.

\begin{tabular}{|c|c|c|c|c|c|}
\hline \multirow[b]{2}{*}{ Animals (Sex, Strain) } & \multirow[b]{2}{*}{ Dose $(\mathrm{mg} / \mathrm{kg})$, Route of Administration, Duration of Treatment } & \multicolumn{3}{|c|}{ Effects } & \multirow[b]{2}{*}{ Reference } \\
\hline & & Behavioral/Other & $\begin{array}{l}\text { Electrophysiological/ } \\
\text { Functional }\end{array}$ & $\begin{array}{c}\text { Histopathological/ } \\
\text { Biochemical/Molecular }\end{array}$ & \\
\hline \multicolumn{6}{|c|}{ Diabetic Painful Neuropathy (DPN) } \\
\hline $\begin{array}{c}\text { Female } \\
\text { Wistar Albino rats }\end{array}$ & $\begin{array}{l}\mathrm{STZ}(50 \mathrm{mg} / \mathrm{kg} \text {, i.p. })+\text { curcumin }(60 \mathrm{mg} / \mathrm{kg} \text {, oral, } 21 \text { days }) \\
\text { Non-diabetic rats + curcumin }(60 \mathrm{mg} / \mathrm{kg} \text {, oral, } 21 \text { days })\end{array}$ & Not tested & Not tested & $\begin{array}{c}\downarrow \text { MDA, TOS, OSI, and NO in brain and sciatic } \\
\text { tissues } \\
\uparrow \text { TAS in brain and sciatic tissues }\end{array}$ & [94] \\
\hline $\begin{array}{l}\text { Male Albino mice of Laka } \\
\text { strain }\end{array}$ & 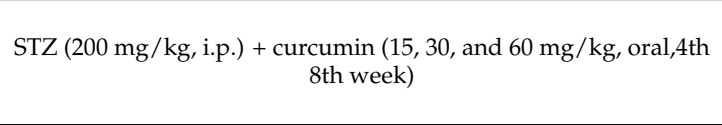 & $\begin{array}{c}\downarrow \text { Plasma glucose level } \\
\uparrow \text { Body weight } \\
\begin{array}{c}\uparrow \text { Thermal hyperalgesia (tail immersion warm } \\
\text { water test and hotplate test) }\end{array}\end{array}$ & Not tested & $\begin{array}{c}\downarrow \text { Serum TNF- } \alpha \text { level } \\
\downarrow \text { Brain nitrite level }\end{array}$ & [95] \\
\hline $\begin{array}{c}\text { Male } \\
\text { Sprague-Dawley rats }\end{array}$ & 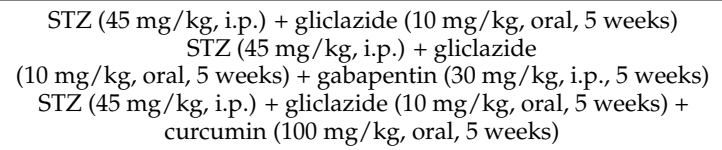 & $\begin{array}{l}\uparrow \text { Thermal hyperalgesia (hotplate and tail } \\
\text { flick test), and mechanical hyperalgesia (tail } \\
\text { pinch test) }\end{array}$ & Not tested & $\begin{array}{c}\checkmark \text { C-peptide level } \\
\downarrow \text { Total NO, serum TNF- } \alpha \text { and MDA }\end{array}$ & [96] \\
\hline $\begin{array}{l}\text { Male Albino mice of Laka } \\
\text { strain }\end{array}$ & 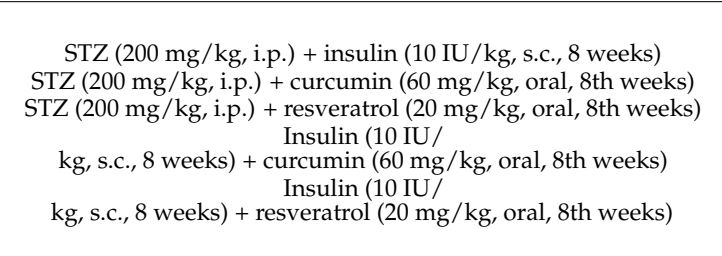 & $\begin{array}{c}\text { Insulin per se } \downarrow \text { Blood glucose level and } \uparrow \\
\text { body weight } \\
\text { Curcumin or resveratrol per se } \downarrow \text { Blood glucose } \\
\text { level and } \uparrow \text { body weight } \\
\text { Combination treatment O blood glucose level } \\
\text { and body weight } \\
\text { Combination treatment } \uparrow \text { thermal hyperalgesia } \\
\text { (tail immersion warm water test and hotplate } \\
\text { test) threshold }\end{array}$ & Not tested & $\begin{array}{l}\text { Combination treatment } \downarrow \text { Serum TNF- } \alpha \text { level } \\
\text { compared to its per se effects } \\
\text { Combination treatment } \downarrow \text { Brain nitrite level } \\
\text { compared to its per se effects }\end{array}$ & [97] \\
\hline
\end{tabular}

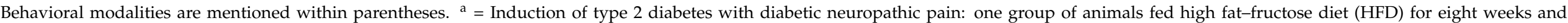

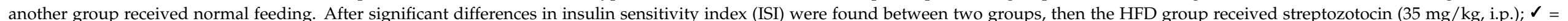

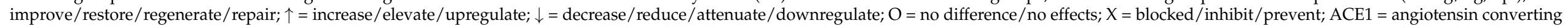

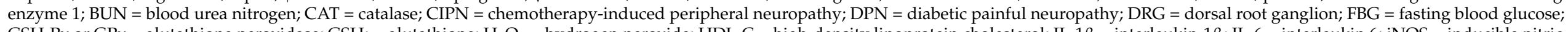

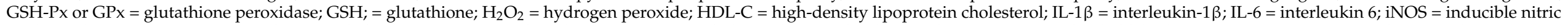

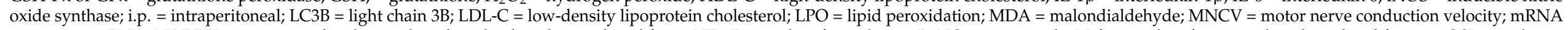

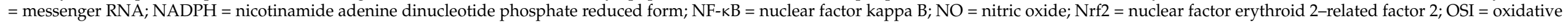

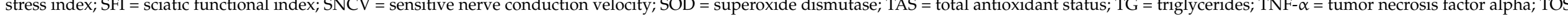
$=$ total oxidant status. 


\subsection{Chemotherapy-Induced Peripheral Neuropathy (CIPN)}

The treatment of cancer with different anticancer agents, including vinca alkaloids, platinum drugs (cisplatin and oxaliplatin), taxanes, and other chemotherapeutic drugs, leads to CIPN, which affects $30-40 \%$ of patients [98]. The symptoms of CIPN initiate with the onset of chemotherapy and improve with the completion of the therapy. However, $25-30 \%$ patients experience pain or unpleasant paresthesia, which even persists after chemotherapy completion [99]. Moreover, CIPN could potentially lead to a decrease in the dose of chemotherapeutics, change to less effective agents, and even cause cessation of the treatment [100]. In terms of cellular mechanisms, anticancer drugs paclitaxel, vincristine, and oxaliplatin lead to mitochondrial damage of sensory neurons in the dorsal root ganglion (DRG), leading to the increased production of ROS [101-104]. Chemotherapy leads to the cellular respiration impairment and decreases the production of adenosine triphosphate (ATP). Therefore, promoting mitochondrial respiration and restoring mitochondrial bioenergetics provide protection against CIPN $[105,106]$. Furthermore, the anticancer drug treatment leads to the reduction in antioxidative enzymes, such as superoxide dismutase (SOD) and catalase (CAT), causing an imbalance between oxidant and antioxidant molecules $[101,104,107]$. This imbalance promotes the cellular apoptotic pathways, leading to degeneration of peripheral sensory fibers and other inflammatory events $[108,109]$. Therefore, antioxidant therapy is considered as an effective treatment against CIPN [110].

Table 2 summarizes the effects of curcumin on CIPN. Curcumin improved platinum drug cisplatin or oxaliplatin-induced thermal (heat or cold) and mechanical hypersensitivity [85-87], and formalin test [87] in various strains of rodent models. However, Al Moundhri et al. [88] reported that curcumin could not attenuate cisplatin- or oxaliplatininduced painful behavioral outcomes. The study attributed a few factors, such as low number of animals in each treatment group, administration of low concentration of curcumin, and other unknown factors to this effect [88]. Curcumin also did not exert any impairment of neuromuscular coordination, indicating that curcumin did not alter motor coordination [88].

Electrophysiological parameters, such as MNCV and sensory nerve conduction velocity (SNCV) provide important insights into the function of sciatic nerves, showing the severity of nerve injury [111]. In rodents, curcumin increased both MNCV and SNCV, showing its favorable effects on functional deficits caused by the platinum drugs $[85,86]$. Furthermore, curcumin attenuated alkaloid vincristine-induced sciatic functional loss by increasing level of sciatic functional index (SFI) in male Swiss albino mice [87]. The results further confirm the protective effects of curcumin against chemotherapy-induced neuropathy [87]. The improvement in histopathology of the sciatic nerve, blockade of nuclear, nucleolar atrophy, and neuronal loss supported the protective effects of curcumin against platinum-induced neurotoxicity [86,88]. Al Moundhri et al. [88] also explored coadministration of curcumin with either oxaliplatin or cisplatin and reported an insignificant reduction in the platinum concentration in the sciatic nerve. The result indicates an interesting neuroprotective activity of curcumin in which concomitant treatment of curcumin did not affect the therapeutic efficacy of platinum drugs [88]. However, more research must be conducted to further confirm the neuroprotective and anticancer activities of curcumin. $\mathrm{Al}$ Moundhri et al. [88] also reported that curcumin reduced oxaliplatin and cisplatin-induced increase in plasma neurotensin, providing an insight into neurotensin quantification as a biomarker of platinum-based drug neurotoxicity. Furthermore, curcumin exerted its antinociceptive activity against CIPN by modulating several markers of oxidative stress, antioxidant enzymes, and inflammatory cytokines [84,85,87]. Curcumin exerted higher efficacy in decreasing oxidative stress markers and increasing the endogenous antioxidative enzymes compared to standard drugs, including pregabalin selective Cav 2.2 (a2d subunit) channel antagonist [87]. In summary, the antinociceptive activity of curcumin against CIPN could be attributed to its multiple actions, including attenuating pain behaviors, increasing $\mathrm{MNCV}, \mathrm{SNCV}$, and SFI, and suppressing inflammatory proteins and cytokines. 


\subsection{Diabetic Painful Neuropathy (DPN)}

According to a report by the Centers for Disease Control and Prevention, about 30.3 million people have diabetes, including $9.4 \%$ of adults [112]. In the United States, 50\% of diabetic patients $[113,114]$ are affected by DPN. Burning, excruciating stabbing pain, numbness, tingling sensation, paresthesia, and hyperesthesia coupled with the aching of feet or hands are some distinguished characteristic features reported in patients with DPN $[115,116]$.

The effects of curcumin on DPN are summarized in Table 2. Curcumin received much attention in treating DPN and its associated complications in rodent models due to its relative safety and inexpensiveness [89-97]. Curcumin modulated STZ-induced changes in body weights in two different ways, by either increasing the STZ-induced reduction in body weight $[89,95,97]$ or preventing/decreasing STZ-induced increase in body weight $[91,93]$. Hyperglycemia is the classical diagnostic marker in both type 1 and type 2 diabetes and is the major cause of diabetic neuropathy [117]. Curcumin significantly reduced elevated blood glucose levels in both mice and rat models of diabetes [93,95,97].

Pain-associated behaviors in diabetic animals are measured as exaggerated responses to painful stimuli (hyperalgesia) or nocifensive responses to normally innocuous stimuli (allodynia) [118]. Curcumin attenuated diabetes-induced thermal [89-91,93,95-97] and mechanical $[89-93,96]$ hypersensitivities. Furthermore, curcumin showed protective effects against renal complications of diabetes as evidenced by a significant decrease in blood urea nitrogen (BUN), creatinine, and renal angiotensin converting enzyme 1 (ACE1) [89], an enzyme that is reported in many tissues, including kidneys and nerves [119]. The study also compared the renal protective effects of curcumin with captopril, an ACE inhibitor with antioxidant and anti-inflammatory properties [120]. However, captopril exerted significantly higher protective effects against renal complications of diabetes than curcumin did, which could be attributed to the more potent ACE inhibitory effects of captopril than curcumin.

Oxidative stress and inflammation are the two major factors that contribute to the pathophysiology of diabetes and its complications [121,122]. Curcumin ameliorated oxidative stress in DPN models by increasing the key enzymes for antioxidant defense, such as SOD [92], and by increasing total antioxidant capacity (TAS) [94]. TAS provides protection from the neurological damage caused by diabetes-induced oxidative stress [123,124]. It also provides important information on the total antioxidant content in a biological system $[123,124]$. Curcumin also exerted its antioxidant properties by reducing or scavenging several oxidative stress markers, such as the lipid peroxidation marker MDA [92,94,96], hydrogen peroxide $\left(\mathrm{H}_{2} \mathrm{O}_{2}\right)$ [92], nitric oxide (NO) [94-97], and oxidative stress index (OSI) and total oxidant status (TOS) [94]. OSI and TOS indicate a total concentration of all free radicals generated by diabetes-related oxidative damage [123,125]. Zhao et al. [92] reported that curcumin ameliorated the protein expressions of nicotinamide adenine dinucleotide phosphate reduced form (NADPH) oxidase subunits gp91 phox and $\mathrm{p} 47^{\mathrm{phox}}$. The phosphorylation activates NADPH oxidases, leading to the generation of ROS, including $\mathrm{H}_{2} \mathrm{O}_{2}$. Therefore, decreases in gp91phox and p47phox could lead to the decrease in oxidative stress [126-129]. In addition, curcumin exerted its anti-inflammatory properties by decreasing the production of pro-inflammatory cytokine TNF- $\alpha[89,93,95-97]$ or its receptor 1 (TNF- $\alpha$ receptor 1) [93]. In comparison with a standard antioxidant apocynin, curcumin demonstrated similar antioxidant activity against DPN [92] (Table 2).

\subsection{Sciatic Nerve Chronic Constriction Injury (CCI)}

Animal models of CCI are widely used to study peripheral neuropathic pain. The CCI model of nerve injury possesses two components, inflammatory and nerve injuries, which resemble the pain found in humans [130].

Table 3 summarizes the effects of curcumin on sciatic nerve CCI. Similar to other neuropathic pain models, curcumin alleviated CCI-induced neuropathic pain behaviors, including heat [131-135], mechanical [92,131-133,135,136], and cold [137] hypersensitiv- 
ities. However, Moini Zanjani et al. [137] reported that low doses (12.5 and $25 \mathrm{mg} / \mathrm{kg}$ ) of curcumin did not reduce pain behavior but induced mechanical allodynia. However, a high dose $(50 \mathrm{mg} / \mathrm{kg})$ of curcumin reduced cold allodynia [137]. The results indicate that different doses of curcumin are effective in alleviating CCI-induced pain behaviors. Curcumin alleviated CCI-induced neuropathic pain by inhibiting the expression of nuclear factor kappa B (NF- $\mathrm{kB}$ ) in the spinal cord and reducing the expression of $\mathrm{CX} 3 \mathrm{C}$ chemokine receptor 1 (CX3CR1) in the dorsal spinal cord and DRG [131] as well as attenuating the messenger RNA (mRNA) or protein expressions [135] of an important inflammatory mediator, cyclooxygenase-2 (Cox-2) [138], and its serum level [137]. Cox-2 is constitutively expressed in the dorsal horn of the spinal cord and is upregulated following injury, leading to the transmission of nociceptive input [139,140]. Besides modulating Cox2, curcumin also reduces the serum level of cortisol by inhibiting the upregulated expression of $11 \beta$-hydroxysteroid dehydrogenase type I enzyme (11ßHSD1) [132]. The 11ßHSD1 is a key enzyme that converts cortisone to cortisol in humans, and 11-dehydrocorticosterone to corticosterone in rodents [141]. These glucocorticoids exert their effects through glucocorticoid receptors that play important roles in the maintenance and development of neuropathic pain by regulating the function and expression of N-methyl-D-aspartate receptor (NMDAR) [142]. Yu et al. [133] reported that curcumin exerted anti-allodynic activity by blocking the immunohistochemical and protein expressions of N-methyl-D-aspartate receptor subunit NR1 (NMDAR NR1) in the spinal cord and DRG. However, Jeon et al. [136] reported that curcumin did not change the protein expression of NR1 in DRG. This discrepancy could be attributed to the dose and duration of curcumin treatment. Yu et al. employed $100 \mathrm{mg} / \mathrm{kg}$ of curcumin for 14 days [133], whereas Jeon et al. [136] used $50 \mathrm{mg} / \mathrm{kg}$ of curcumin for 7 days in rats. The treatment for 7 days [136] was probably too short to see the curcumin-induced changes at the central sensitization. Therefore, future studies are required to examine the long-term treatment of curcumin on central sensitization in rodent chronic neuropathic pain model. In addition, NMDAR-mediated activation of brain-derived neurotrophic factor (BDNF) is associated with the enrichment of p300/CREBbinding protein (CBP) at the BDNF gene promoter I [143]. Curcumin exerted its therapeutic activity by downregulating the recruitment of $\mathrm{p} 300 / \mathrm{CBP}$ and histone acetyltransferase (HAT) (acetyl-Histone H3/acetyl-Histone H4) to the BDNF promoter [135]. Curcumin also downregulated p300/CBP HAT activity-mediated gene expression of Cox-2 [135]. 
Table 3. Effects of curcumin on sciatic nerve chronic constriction injury (CCI).

\begin{tabular}{|c|c|c|c|c|}
\hline \multirow[b]{2}{*}{ Animals (Sex, Strain) } & \multirow[b]{2}{*}{$\begin{array}{l}\text { Dose (mg/kg), Route of Administration, } \\
\text { Duration of Treatment }\end{array}$} & \multicolumn{2}{|r|}{ Effects } & \multirow[b]{2}{*}{ Reference } \\
\hline & & Behavioral Evaluation/Other Diabetic & $\begin{array}{c}\text { Histopathological/ } \\
\text { Biochemical/Molecular }\end{array}$ & \\
\hline Male Sprague-Dawley rats & $\mathrm{CCI}+$ curcumin $(100 \mathrm{mg} / \mathrm{kg}$, peritoneal, 14 days $)$ & $\begin{array}{c}\checkmark \text { Mechanical allodynia (von Frey) and thermal } \\
\text { hyperalgesia (Hargreaves test) }\end{array}$ & $\begin{array}{l}\text { X Immunohistochemical and protein expressions of NMDAR-NR1 in } \\
\text { spinal cord and DRG }\end{array}$ & [133] \\
\hline Male Sprague-Dawley rats & CCI + curcumin $(100 \mathrm{mg} / \mathrm{kg}$, i.p., 14 days $)$ & $\begin{array}{c}\uparrow \text { Thermal withdrawal latency (heat stimulus) } 7 \text { days after } \\
\text { surgery and mechanical withdrawal threshold (von Frey) } 10 \\
\text { days after surgery }\end{array}$ & $\begin{array}{c}\downarrow \text { NF-KB p65 protein expression in lumbar spinal cord and DRG } 7 \text { days } \\
\text { after surgery } \\
\begin{array}{c}\downarrow C X 3 C R 1 \text { positive expression in spinal dorsal horn and DRG } 7 \text { days } \\
\text { after surgery }\end{array}\end{array}$ & [131] \\
\hline Male Sprague-Dawley rats & CCI + curcumin $(100 \mathrm{mg} / \mathrm{kg}$, peritoneal, 14 days $)$ & $\begin{array}{l}\checkmark \text { Thermal hyperalgesia (Hargreaves test) and paw } \\
\text { withdrawal mechanical threshold (von Frey) on day } 14\end{array}$ & $\begin{array}{c}\downarrow \text { Serum cortisol concentration } \\
\text { X Upregulated expression of 11 } \beta \text { HSD1 in spinal dorsal } \\
\text { horn and DRG }\end{array}$ & [132] \\
\hline Male Wistar rats & $\mathrm{CCI}+\operatorname{curcumin}(12.5,25$ and $50 \mathrm{mg} / \mathrm{kg}$, i.p., 7 days $)$ & $\begin{array}{l}\text { O Mechanical allodynia (von Frey) } \\
\text { High dose } \downarrow \text { Cold allodynia (acetone test) }\end{array}$ & High dose $\downarrow$ Serum concentration of cyclooxygenase 2 & [137] \\
\hline Male Sprague-Dawley rats & CCI $+\operatorname{curcumin}(20,40$, or $60 \mathrm{mg} / \mathrm{kg}$, i.p., 14 days $)$ & $\begin{array}{c}\downarrow \text { Thermal hyperalgesia (Hargreaves test) and mechanical } \\
\text { allodynia (von Frey) }\end{array}$ & $\begin{array}{c}\downarrow \text { Recruitment of } \mathrm{p} 300 / \mathrm{CBP} \text { and acetyl-histone H3/acetyl-histone H4 to } \\
\quad \text { the promoter of BDNF and Cox-2 genes } \\
\downarrow \text { mRNA and protein expressions of BDNF and Cox-2 in spinal cord }\end{array}$ & [135] \\
\hline Male Sprague-Dawley rats & $\mathrm{CCI}+$ curcumin $(50 \mathrm{mg} / \mathrm{kg}$, oral, 7 days $)$ & $\downarrow$ Mechanical allodynia (von Frey) & O Protein expressions of p-ERK, p-JNK, and p-NR1 in DRG & [136] \\
\hline Male C57BL/6J mice & $\begin{array}{c}\mathrm{CCI}+\operatorname{curcumin}(5,15 \text { or } 45 \mathrm{mg} / \mathrm{kg} \text {, oral, twice per } \\
\text { day for } 3 \text { weeks })\end{array}$ & $\begin{array}{c}\text { Chronic treatment } \downarrow \text { Thermal hyperalgesia (hotplate) and } \\
\text { mechanical allodynia (von Frey) } \\
\text { Depletion of descending noradrenaline (NA) by 6-OHDA X } \\
\text { Mechanical allodynia, but not thermal hyperalgesia } \\
\text { Depletion of 5-HT by PCPA X thermal hyperalgesia but not } \\
\text { mechanical allodynia } \\
\text { Antagonists } \beta \text {-AR (propranolol) but not } \alpha \text {-AR } \\
\text { (phentolamine) X Mechanical allodynia } \\
\beta 2 \text {-AR (ICI 118,551) X Mechanical allodynia } \\
5 \text {-HT1A (WAY-100635) X Thermal hyperalgesia } \\
\text { Antagonists Delta-opioid (naltrindole hydrochloride) } \downarrow \\
\text { Mechanical allodynia } \\
\text { Mu-opioid ( } \beta \text {-funaltrexamine) X Thermal hyperalgesia } \\
\text { Kappa-opioid (nor-binaltorphimine) O Mechanical } \\
\text { allodynia or thermal hyperalgesia }\end{array}$ & $\begin{array}{c}\text { Chronic treatment increased spinal monoamine serotonin and its } \\
\text { metabolite MHPG } \\
\text { Did not alter other monoamines/ } \\
\text { metabolites (NA, 5-HIAA, dopamine and DOPAC) }\end{array}$ & [134] \\
\hline \multicolumn{5}{|c|}{ Combination Study } \\
\hline Male Sprague-Dawley rats & $\begin{array}{c}\text { CCI }+ \text { curcumin }(100 \mathrm{mg} / \mathrm{kg} \text {, oral, } 14 \text { days }) \\
\text { CCI + tramadol }(10 \mathrm{mg} / \mathrm{kg} \text {, i.p., } 14 \text { days }) \\
\text { CCI + chronic constriction release (CCR })+ \text { curcumin } \\
(100 \mathrm{mg} / \mathrm{kg} \text {, oral, } 14 \text { days }) \\
\text { CCI }+ \text { CCR }+ \text { tramadol }(10 \mathrm{mg} / \mathrm{kg}, \text { i.p., } 14 \text { days }) \\
\text { CCI }+ \text { curcumin }(100 \mathrm{mg} / \mathrm{kg}, \text { oral, } 14 \text { days })+ \\
\text { tramadol }(10 \mathrm{mg} / \mathrm{kg}, \text { i.p., } 14 \text { days })\end{array}$ & $\begin{array}{c}\mathrm{CCI}+\text { tramadol, and CCI }+\mathrm{CCR}+\text { tramadol } \uparrow \text { Thermal } \\
\text { hyperalgesia (heat stimulus) } \\
\mathrm{CCI}+\text { tramadol, and CCI }+\mathrm{CCR}+\text { tramadol } \uparrow \text { Mechanical } \\
\text { allodynia (dynamic plantar test) } \\
\text { O Cold-induced pain (cold plate test) }\end{array}$ & $\begin{array}{c}\downarrow \text { Sciatic and DRG TNF- } \alpha \text { in CCI }+ \text { CCR }+ \text { tramadol } \\
\uparrow \text { Sciatic IL-10 in CCI }+ \text { CCR }+ \text { tramadol, whereas } \uparrow \text { DRG IL-10 in CCI + } \\
\text { tramadol followed by CCI }+ \text { CCR + tramadol } \\
\uparrow \text { Number of regenerated axons in CCI }+ \text { CCR + curcumin and CCI + } \\
\text { CCR + tramadol }\end{array}$ & [144] \\
\hline
\end{tabular}

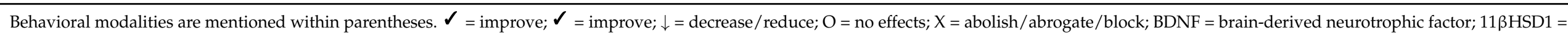

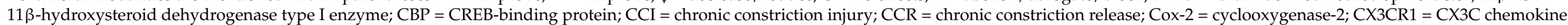

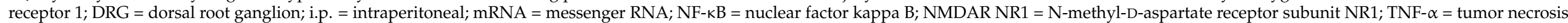
factor alpha. 
Curcumin turned out to be less efficacious in a chronic constriction injury-chronic constriction release (CCI-CCR) model of neuropathic pain when compared to a neuropathic drug tramadol hydrochloride, a synthetic opioid from the aminocyclohexanol group [145]. However, curcumin was effective in inducing high regeneration and decreasing degeneration of nerve tissues in CCR compared to tramadol [144]. Findings from Ceyhan et al. [144] indicate that long-term use of curcumin in surgical constriction release may exert beneficial effects in ameliorating CCI-induced neuropathic pain.

Zhao et al. [134] explored the underlying mechanisms of antinociceptive action of curcumin in CCI-induced neuropathic pain. The study proposed that descending monoamine system spinal beta2-ARs and delta opioid receptors maintain the anti-allodynic activity of curcumin on mechanical stimuli, whereas descending serotonergic system coupled with spinal 5-HT1A receptors and mu opioid receptors are required for the anti-hyperalgesic activity of curcumin on thermal stimuli [134].

\subsection{Other Peripheral Neuropathic Pain Models \\ 4.5.1. Sciatic Nerve Crush (SNC) Injury}

Compression, fracture, crush, wound, and laceration lead to the injury of sciatic nerves [146,147], and to the partial or total autonomic, motor, and sensory function loss [148]. A sciatic nerve crush model in rodents is widely used to represent axonotmesislike moderate peripheral neuropathy $(\mathrm{PN})$ injury and is characterized by myelin sheath destruction and Wallerian degeneration [149].

Table 4 summarizes the effects of curcumin on SNC. Curcumin demonstrated neuroprotective effects on peripheral nerve injury by promoting nerve regeneration [150-152] and protecting the injured DRG and sciatic nerve structures [153,154]. In a combination study, curcumin was administered with melatonin, a drug that is used in nerve tissue recovery and repair [155]. Since melatonin is affected by light and dark, the study comparatively evaluated the effects of curcumin and melatonin in light and dark periods [156]. The results showed that curcumin exerted better efficacy in stimulating nerve regeneration compared to melatonin. However, the effects of curcumin did not differ between the light and dark periods of treatments, but melatonin showed significantly better efficacy in the dark compared to light group [151]. Therefore, future studies should explore the effects of curcumin in human nerve regeneration. Furthermore, Ma et al. [152] reported that high doses of curcumin $(100 \mathrm{mg} / \mathrm{kg}$ and $300 \mathrm{mg} / \mathrm{kg})$ induced similar nerve regeneration effects as mecobalamin, a neuroprotective agent commonly used as a neuroprotective agent against neurodegenerative diseases [157]. All the evidence reinforces the neuroprotective effects of curcumin in promoting nerve regeneration and accelerating motor functional recovery. 
Table 4. Effects of curcumin on sciatic nerve crush injury (SNC), spared nerve injury (SNI), and sciatic nerve ligation (SNL).

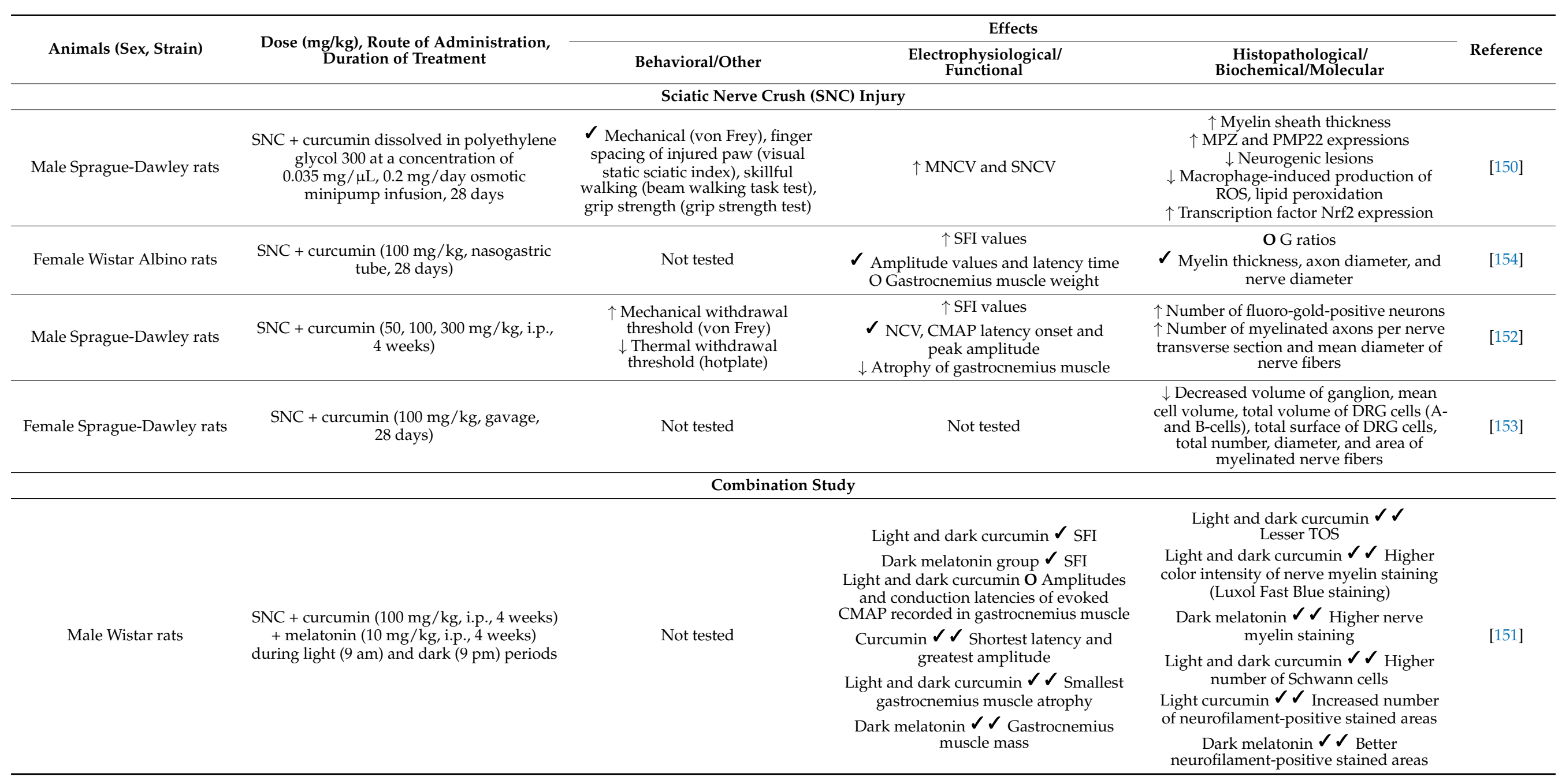


Table 4. Cont.

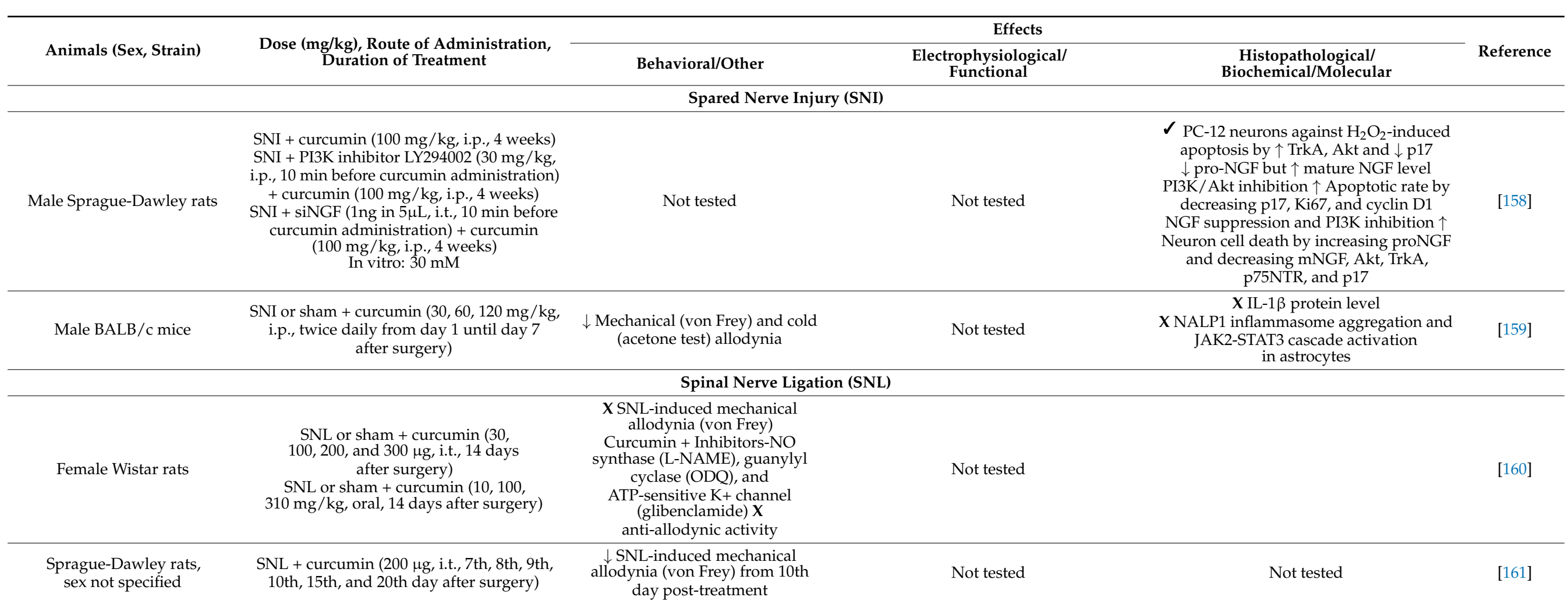

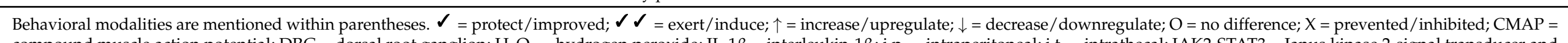

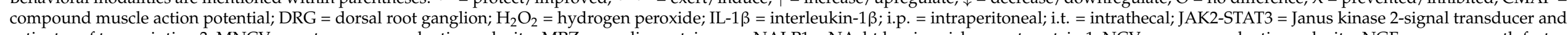

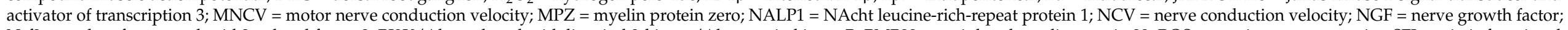

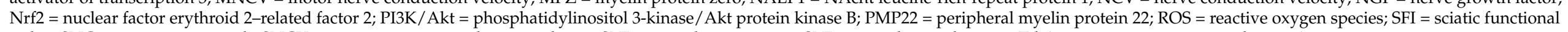
index; $\mathrm{SNC}=$ sciatic nerve crush; $\mathrm{SNCV}=$ sensitive nerve conduction velocity; $\mathrm{SNI}=$ spared nerve injury; $\mathrm{SNL}=$ spinal nerve ligation; TrkA = tropomyosin receptor kinase $\mathrm{A}$. 


\subsubsection{Spared Nerve Injury (SNI)}

SNI model resembles the stimulus-evoked pain that is observed under clinical settings of neuropathic pain syndrome [162,163]. Table 4 summarizes the effects of curcumin on SNI. Curcumin reduced SNI-induced neuropathic pain behaviors by activating either the tropomyosin receptor kinase A (TrkA) and phosphatidylinositol 3-kinase/Akt protein kinase B (PI3K/Akt) cell survival signaling pathway [158] or the Janus kinase 2-signal transducer and activator of transcription 3 (JAK2-STAT3) signaling pathway [159]. Nerve damage induces neuroinflammation [164], which leads to the upregulation of proinflammatory cytokines [164], including IL-1 $\beta$, that contribute to the development and maintenance of neuropathic pain [165]. Curcumin downregulated the production of mature IL-1 $\beta$ in the spinal cord and thus attenuated SNI-induced neuropathic pain [159]. Furthermore, curcumin induced the anti-allodynic activity by inhibiting the NAcht leucinerich-repeat protein 1 (NALP1) inflammasome and activating the JAK2-STAT3 pathway in astrocytes [159]. On the other hand, curcumin demonstrated protective effects against injured neurons by stimulating the release of nerve growth factor (NGF) and further activating the TrkA and PI3K/Akt cell survival signaling pathway [158].

\subsubsection{Spinal Nerve Ligation (SNL)}

Kiso et al. [166] developed a L5/L6 mice spinal nerve ligation model, which is employed in studying neuropathic pain. In this nerve ligation model, mechanical allodynia develops at day 1 and lasts for two months after the surgery.

Table 4 summarizes the effects of curcumin on SNL. Lee et al. [161] reported that intrathecal administration of curcumin alleviated SNL-induced allodynia, but they did not explore the underlying mechanisms of action. On the other hand, Pastrana-Quintos et al. [160] reported that both oral and intrathecal curcumin induced anti-allodynic activity in an SNL model of neuropathic pain and that the anti-allodynic effect was mediated via the nitric oxide-cyclic guanosine monophosphate-adenosine triphosphate-sensitive potassium + channels pathway. Furthermore, the highest dose of oral $(310 \mathrm{mg} / \mathrm{kg})$ and intrathecal $(0.3 \mathrm{mg})$ curcumin exerted maximal anti-allodynic effects, and intrathecal curcumin even produced significantly higher anti-allodynic activity compared to gabapentin [160].

\section{Curcumin and Postoperative Pain and Preemptive Analgesia-Preclinical Studies}

\subsection{Postoperative Pain}

Patients perceive postoperative pain as one of the most noxious aspects of surgical pain for which effective control measures are lacking [167-169]. Table 5 summarizes the effects of curcumin on postoperative pain and preemptive analgesia. Acute treatment of curcumin demonstrated anti-hyperalgesic activity by dose-dependently reversing mechanical hyperalgesia, whereas repeated treatment facilitated the recovery of postoperative pain [170]. However, repeated treatment before surgery did not exert impact on the prevention or reduction in postoperative pain [170]. The results emphasize that acute curcumin treatment may be useful in treating postoperative pain. Curcumin also exerted its analgesic activity by alleviating incision-induced inflammation, spontaneous pain, functional gait abnormalities, and hyperalgesic priming [171]. Although curcumin did not alter the pro- or anti-inflammatory cytokines at the peri incisional level, it augmented transforming growth factor- $\beta$ (TGF- $\beta$ ), which is implicated to inhibit nociception in both inflammatory and neuropathic pain models [172]. Ju et al. [173] provided important insights into the underlying mechanisms of the antinociceptive activity of curcumin in postoperative pain. The results showed that antagonizing the gamma-aminobutyric acid (GABA) receptors abrogated the curcumin-induced anti-hyperalgesic activity, and curcumin treatment elevated the mRNA expression of GABA-A and GABA-B in the incised spinal cord. On the other hand, antagonizing the opioid receptors reversed the anti-hyperalgesic activity of curcumin but did not alter the mRNA expression of opioid receptors in the spinal cord, indicating the indirect involvement of opioid receptors in mediating curcumin antinociception of postoperative pain [173]. Together, the findings conclude that spinal GABA receptors are important in 
modulating postoperative pain and that curcumin increases the synthesis of GABA mRNA in the spinal cord, thus mediating the antinociception of postoperative pain. Therefore, postoperative pain can be treated or prevented with spinal GABA receptor agonists.

Table 5. Effects of curcumin on postoperative and preemptive analgesia.

\begin{tabular}{|c|c|c|c|c|}
\hline \multirow[b]{2}{*}{ Animals (Sex, Strain) } & \multirow{2}{*}{$\begin{array}{c}\text { Dose (mg/kg), Route of Administration, } \\
\text { Duration of Treatment }\end{array}$} & \multicolumn{2}{|l|}{ Effects } & \multirow[b]{2}{*}{ Reference } \\
\hline & & Behavioral/Other & $\begin{array}{l}\text { Histopathological/ } \\
\text { Biochemical/Molecular }\end{array}$ & \\
\hline \multicolumn{5}{|c|}{ Postoperative Pain } \\
\hline Male Sprague-Dawley rats & $\begin{array}{l}\text { Incision + curcumin }(0.01,0.03 \\
\text { or } 0.1 \mathrm{mg}, \text { i.t. })\end{array}$ & $\begin{array}{c}\downarrow \text { Mechanical hypersensitivity (von Frey) } \\
\text { Antagonists GABA-A (bicuculline) and } \\
\text { GABA-B (saclofen) X } \\
\text { antinociceptive activity } \\
\text { Antagonists mu (CTOP), delta } \\
\text { (naltrindole), and kappa (GNTI) opioid } \\
\text { receptor X antinociceptive activity }\end{array}$ & $\begin{array}{c}\uparrow \text { mRNA expressions of } \\
\text { GABA-A and GABA-B in } \\
\text { incised spinal cord } \\
\text { O mRNA expressions of } \\
\text { opioid receptors in incised } \\
\text { spinal cord }\end{array}$ & [173] \\
\hline Male C57BL/ 6 mice & $\begin{array}{l}\text { Incision + curcumin ( } 50 \mathrm{mg} / \mathrm{kg} \text {, i.p., } \\
4 \text { days })\end{array}$ & $\begin{array}{c}\downarrow \text { Mechanical hypersensitivity (von Frey) } \\
\downarrow \text { Thermal hypersensitivity } \\
\text { (Hargreaves test) } \\
\downarrow \text { Prostaglandin-induced } \\
\text { hyperalgesic priming } \\
\text { O Paw edema (laser sensor technique) } \\
\text { and hindpaw temperature (fine } \\
\text { wire thermocouple) } \\
\text { O Morphine-induced place preference } \\
\text { (affective component of incision } \\
\text { measured by conditioned CPP) } \\
\text { X Functional abnormalities in gait indices } \\
\text { (gait analysis) }\end{array}$ & $\begin{array}{c}\text { O IL-1 } \beta, \text { IL-6, macrophage } \\
\text { inflammatory protein-1 } \alpha \text { at } \\
\text { peri-incisional level } \\
\text { O IL-10 at } \\
\text { peri-incisional level } \\
\uparrow \text { TGF- } \beta \text { levels at } \\
\text { peri-incisional level }\end{array}$ & [171] \\
\hline Male Sprague-Dawley rats & $\begin{array}{l}\text { Acute treatment: Incision + curcumin } \\
\text { (10-40 mg/kg, oral, } 1 \text { day after surgery) } \\
\text { Repeated treatment: Incision + curcumin } \\
\text { (10-40 mg } / \mathrm{kg} \text {, oral, } 20 \mathrm{~min} \text { before to } \\
\text { surgery and twice daily for } 7 \text { days }) \\
\text { Repeated treatment before surgery: } \\
\text { Curcumin ( } 10-40 \mathrm{mg} / \mathrm{kg} \text {, oral, twice } \\
\text { daily for } 7 \text { days before surgery) + incision }\end{array}$ & $\begin{array}{c}\text { Acute treatment } \downarrow \text { Mechanical } \\
\text { hyperalgesia (von Frey) } \\
\text { Repeated treatment before surgery } \mathbf{O} \\
\text { Mechanical hyperalgesia } \\
\text { Repeated treatment } \\
\text { Mechanical hyperalgesia } \\
\text { Repeated treatment } \checkmark \text { Recovery } \\
\text { from surgery } \\
\text { Repeated treatment before surgery O } \\
\text { recovery rate } \\
\text { O Locomotor activity (YLS-1B apparatus) }\end{array}$ & Not tested & [170] \\
\hline \multicolumn{5}{|c|}{ Preemptive Analgesia } \\
\hline Common crossbred swine & $\begin{array}{c}\text { Curcumin }[(130 \mathrm{mg} / \mathrm{kg} \text {, oral, } 3 \text { days prior } \\
\text { to CPB and extracorporeal } \\
\text { support surgery }\end{array}$ & Not tested & $\begin{array}{l}\downarrow \text { Concentrations of IL- } 6 \text {, } \\
\text { TNF- } \alpha \text {, and ICAM- } 1\end{array}$ & [174] \\
\hline $\begin{array}{l}\text { Male Wistar Bratislava } \\
\text { Albino rats }\end{array}$ & $\begin{array}{c}\text { Nitroglycerin (NTG) }(1 \mathrm{mg} / 100 \mathrm{~g} \text { body } \\
\text { weight i.p.) + curcumin }(10 \mathrm{mg} / 100 \mathrm{~g} \\
\text { body weight, i.p., } 14 \text { days before } \\
\text { NTG administration) }\end{array}$ & $\begin{array}{l}\downarrow \text { Number of flinches and shakes } \\
\quad \text { (formalin test) }\end{array}$ & $\begin{array}{c}\downarrow \text { Blood pressure } \\
\downarrow \text { MDA, NO, TOS, and thiol } \\
\text { compound } \\
\uparrow \text { TAC }\end{array}$ & [175] \\
\hline Female Wistar Albino rats & $\begin{array}{l}\text { Curcumin ( } 400 \mathrm{mg} / \mathrm{kg} \text {, oral, } 45 \mathrm{~min} \\
\text { before formalin injection) }\end{array}$ & $\begin{array}{c}\downarrow \text { Thermal pain (hotplate test) } \\
\downarrow \text { Number of flinches (formalin test) }\end{array}$ & Not tested & [176] \\
\hline
\end{tabular}

Behavioral modalities are mentioned within parentheses. $\checkmark=$ improve, facilitate; $\downarrow=$ alleviate $/$ decrease $/$ attenuate; $\mathrm{O}=$ no effects $/$ no alteration; $\mathrm{X}=$ abrogate/prevent; $\mathrm{CPB}=$ cardiopulmonary bypass; $\mathrm{CPP}=$ conditioned placed preference; $\mathrm{GABA}=$ gamma-Aminobutyric acid; ICAM-1 = intercellular adhesion molecule 1; IL-1 $\beta=$ interleukin-1 $\beta$; IL-6 = interleukin 6; i.p. = intraperitoneal; i.t. = intrathecal; MDA $=$ malondialdehyde mRNA $=$ messenger RNA; TAC $=$ total antioxidative capacity; TGF $\beta=$ transforming growth factor $\beta ;$ TNF- $\alpha=$ tumor necrosis factor alpha; $\mathrm{TOS}=$ total oxidative status.

\subsection{Preemptive Analgesia}

Preemptive analgesia is an antinociceptive treatment that is applied to prevent altered processing of the afferent input that amplifies postoperative pain by preventing central sensitization caused by incisional and inflammatory injuries, and it covers both the period of surgery and the initial postoperative period. The nature of surgery determines the balance between incisional injury and inflammatory injury, with inflammation injury being a dominant factor $[177,178]$. The application of preemptive analgesia is more effective in reducing surgery-induced nociceptive pain transmission when compared to the application of analgesic treatment provided after surgery [179].

Nurullahoglu et al. [176] suggested the preemptive analgesic effects of curcumin on acute thermal and inflammation-induced pain in female Wistar Albino rats. Furthermore, 
the study compared the preemptive effects of curcumin with intraperitoneal administration of diclofenac $(10 \mathrm{mg} / \mathrm{kg})$, a non-steroidal anti-inflammatory drug [180]. Diclofenac exerts controversial preemptive effects, with some studies, showing no differences in the effects in between pre- and postoperative diclofenac-treated patients undergoing laparoscopic tubal ligation [177], while other studies reported that preoperative administration of diclofenac along with ketorolac and piroxicam reduced postoperative pain in patients undergoing laparoscopy [181,182]. Based on Nurullahoglu et al.'s [176] study, both curcumin and diclofenac exerted preemptive analgesic effects. Bulboacs et al. [175] demonstrated the preemptive effects of curcumin in a rodent migraine model. Curcumin induced analgesic effects in both phase I dominated by vasodilation and phase II dominated by inflammation of formalin test [175]. Moreover, curcumin reduced oxidative stress markers and blood pressure and increased TAC. The study also compared the preemptive analgesic effects of curcumin with a beta-1 blocker, propranolol [183], which is effective in treating migraine patients by increasing the temporal distances between migraine attacks [184]. Another drug, indomethacin, exerts antimigraine effects due to its antinociceptive and anti-inflammatory properties [185]. Bulboacs et al. [175] demonstrated that curcumin had superior activity as compared to propranolol- and indomethacin-treated groups, indicating that curcumin could be used as prophylaxis for migraine. In addition to rodent models, the preemptive analgesic property of curcumin was also effective in a swine model of cardiopulmonary bypass (CPB) and extracorporeal support, resulting in a decrease in TNF- $\alpha$ and intercellular adhesion molecule (ICAM-1) expressions [174]. This study in a swine model provides data for the development of a human translational study [174]. However, further studies are needed to explore the underlying mechanisms of preemptive analgesic effects of curcumin.

\section{Curcumin Formulations and Neuropathic Pain-Preclinical Studies}

Preclinical and clinical studies have employed different curcumin formulations synthesized in order to improve the solubility, bioavailability, and pharmacokinetics of curcumin [186-190].For example, in a clinical study, a novel bio-enhanced preparation of curcumin called BCM-95CG (Biocurcumax) showed 6.93- and 6.3-fold higher bioavailability when compared to curcumin and a curcumin-lecithin-piperine formula, respectively [186]. However, Shoba et al. [189] reported that concomitant administration of piperine enhanced the bioavailability, absorption, and serum concentration of curcumin in both rodents and humans with no side effects. Another curcumin formula, Theracurmin, which is curcumin dispersed with colloidal submicron particles, exhibited higher absorption efficiency compared to other curcumin drug-delivery systems, such as BCM-95 (micronized curcumin with turmeric essential oils) and Meriva (curcumin-phospholipid) [187]. A curcumin formulation with a combination of hydrophilic carrier, cellulosic derivatives, and natural antioxidants further showed higher absorption in blood compared to unformulated curcumin [188].

However, only a few studies have looked into the effects of curcumin formulations in neuropathic pain, specifically diabetic and CCI-induced neuropathies [27-34] (Figure 3). Table 6 summarizes the effects of different curcumin formulations on neuropathic pain. Curcumin derivative J147 was reported to possess potent neurogenic and neuroprotective activities and was initially developed to treat neurodegenerative conditions [191,192]. J147 exerted its therapeutic potential by reducing multiple pathogenic pathways associated with the DPN in rodent models [27,33]. Reduced AMP kinase signaling is known to be associated with DPN [193,194]. J147 stimulated the AMPK signaling pathway by increasing its protein and mRNA expressions [27,33]. J147 also ameliorated diabetes-induced mechanical hypersensitivity [27,33], heat hypersensitivity [27], and increased MNCV [27]. Curcumin delivery systems, such as the self-nano emulsifying drug delivery system (SNEDDS) [30] and nanoparticle-encapsulated curcumin (curcumin-polybutylcyanoacrylate nanoparticleencapsulated particles: PEGMA-DMAEMA-MAO) [28] improved diabetes-induced mechanical and thermal hypersensitivities [28,30]. The nanoparticle-encapsulated curcumin decreased the mRNA and protein expressions of purinergic receptor 12 (P2Y12), which is expressed on 
satellite glial cells (SGCs) in DRG [195,196]. P2Y12 is activated by ATP and ADP and plays an important role in transmitting painful signaling [195,197-199]. The decreased expression of P2Y12 by nanoparticle-encapsulated curcumin led to the decrease in pro-inflammatory cytokines IL-1 $\beta$ and connexin 43 (Cx43) and ultimately decreased neuronal excitability in the DRG and resulted in attenuation of diabetes-induced painful behavior [28]. Furthermore, SNEDDS more efficiently reversed diabetes-induced functional, sensorimotor, and biochemical deficits by decreasing neuroinflammation and improving the antioxidative defense system as compared to naïve curcumin [30]. Besides diabetes, curcumin formulae are also effective in attenuating CCI-induced neuropathic pain by decreasing pronociceptive peptides [161] or pro-inflammatory cytokines [32]. A curcumin formula, curcumin-loaded poly (d, l-lactide-coglycolide) nanovesicles (PLGA-CUR), at both low and high doses, attenuated CCI-induced pain behaviors [34]. The results further confirm the better efficacy of curcumin formulations over parent curcumin, which possesses poor bioavailability and is required at high doses to attenuate neuropathic pain.

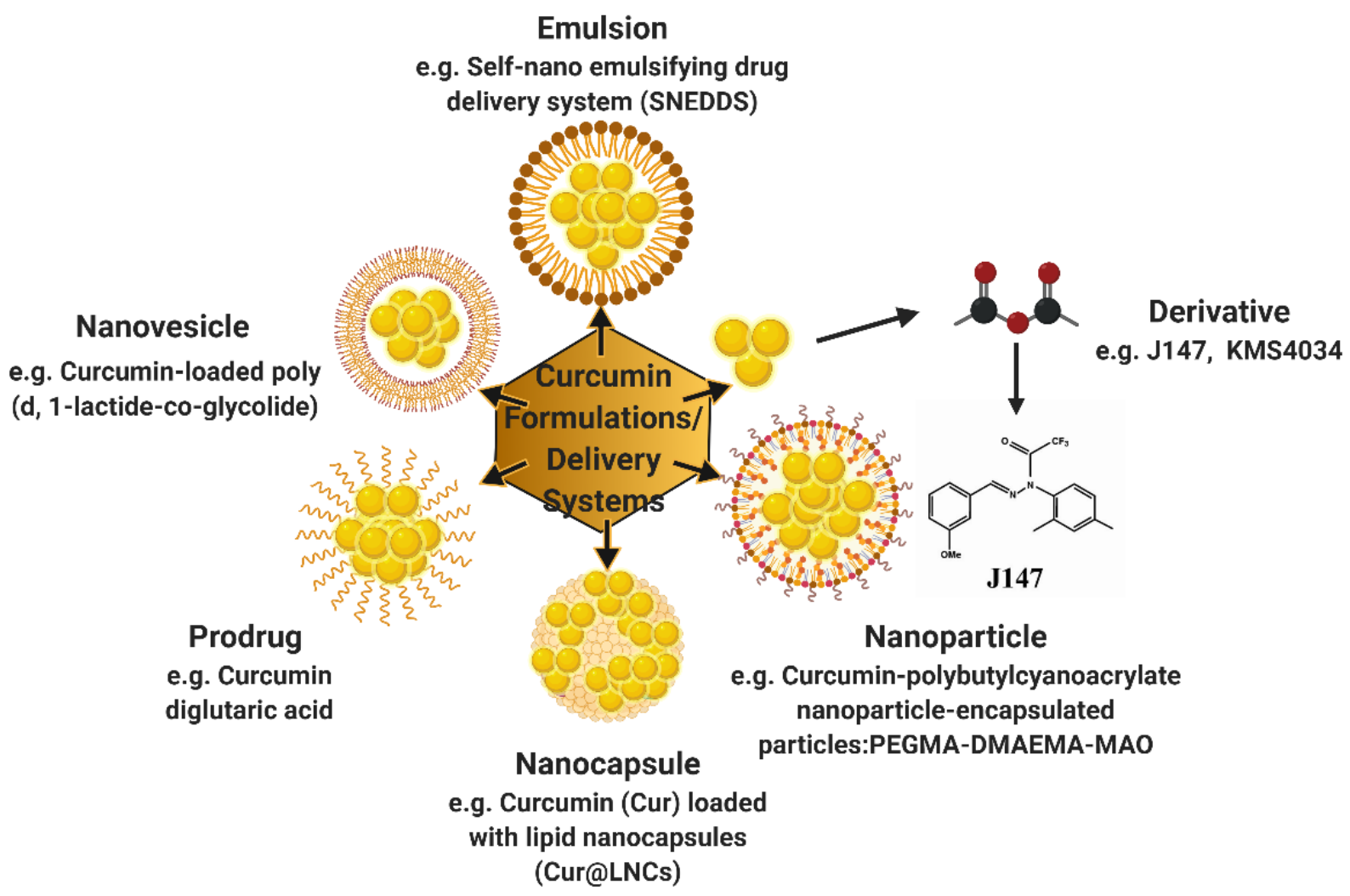

Figure 3. Schematic representations of different curcumin formulations and delivery systems along with their respective examples discussed in the review (created with BioRender).

Together, the efficacy of these curcumin formulations against neuropathic pain supports their applications in clinical investigation. Eventually, further improvement of curcumin formulations would enhance their use as adjuvants to neuropathic drugs. 
Table 6. Effects of different curcumin formulations on neuropathic pain.

\begin{tabular}{|c|c|c|c|c|c|}
\hline \multirow[b]{2}{*}{ Animals (Sex, Strain) } & \multirow{2}{*}{$\begin{array}{l}\text { Dose }(\mathrm{mg} / \mathrm{kg}) \text {, Route of } \\
\text { Administration, Duration of Treatment }\end{array}$} & \multicolumn{3}{|c|}{ Effects } & \multirow[b]{2}{*}{ Reference } \\
\hline & & $\begin{array}{l}\text { Behavioral Evaluation/ } \\
\text { Other Parameters }\end{array}$ & $\begin{array}{l}\text { Electrophysiological/ } \\
\text { Functional Evaluation }\end{array}$ & $\begin{array}{l}\text { Histopathological/ } \\
\text { Biochemical/Molecular Parameters }\end{array}$ & \\
\hline \multicolumn{6}{|c|}{ Diabetic Neuropathy } \\
\hline $\begin{array}{l}\text { Female Swiss Webster mice or } \\
\text { diabetic rats (strain and sex were } \\
\text { not specified) }\end{array}$ & $\begin{array}{c}\mathrm{STZ}-90 \mathrm{mg} / \mathrm{kg} \text {, i.p. } \\
\mathrm{STZ}+\text { phenyl hydrazide derivative J147 } \\
(10,50 \mathrm{mg} / \mathrm{kg} \text {, i.p. oral, } 20 \text { weeks })\end{array}$ & $\begin{array}{c}\downarrow \text { Blood glucose and HbA1c levels } \\
\uparrow \text { Paw thermal response (Hargreaves test) } \\
\downarrow \text { Tactile allodynia (von Frey) } \\
\text { O Sensorimotor function (rotarod test) }\end{array}$ & $\downarrow \mathrm{MNCV}$ & $\begin{array}{l}\downarrow \text { TNFR1, TNFR2, and type I diabetes mellitus } \\
\text { signaling pathways } \\
\uparrow \text { AMPK, and ephrin receptor } \\
\text { signaling pathways } \\
\quad \downarrow \text { Protein levels of } \\
\text { TNF- } \alpha, \text { TSPO, iNOS or GFAP and peripheral } \\
\text { inflammation marker C-reactive protein }\end{array}$ & [27] \\
\hline Male SPF rats & $\begin{array}{c}\mathrm{STZ}-50 \mathrm{mg} / \mathrm{kg} \text {, i.p. } \\
\mathrm{STZ}+\mathrm{J} 147(10 \text { or } 100 \mu \mathrm{M} \text { of at } 10 \mathrm{mg} / \mathrm{kg} \\
\text { weight, } 5 \text { days }) \\
\text { In vitro: } \mathrm{J} 147(10 \text { and } 100 \mu \mathrm{M})\end{array}$ & $\begin{array}{l}\downarrow \text { Mechanical withdrawal threshold } \\
\text { (von Frey) }\end{array}$ & & $\begin{array}{c}\text { O Cell viability and apoptosis of RSC96 } \\
\text { cells } \\
\uparrow \text { AMPK mRNA and protein expression levels } \\
\downarrow \text { TRPA1 mRNA and protein expression levels } \\
\downarrow \text { Calcium reaction level in AITCR } \\
\text { treated RSC96 cells }\end{array}$ & [33] \\
\hline \multicolumn{6}{|c|}{ Nanoparticle-Encapsulated Curcumin } \\
\hline Male Sprague-Dawley & $\begin{array}{c}\mathrm{STZ}-30 \mathrm{mg} / \mathrm{kg} \text {, i.p. } \\
\mathrm{STZ}+\text { nanoparticle-encapsulated } \\
\text { curcumin, } 16 \mathrm{mg} / \mathrm{kg} \text {, sublingual vein, } 7 \mathrm{th}, \\
\text { and } 8 \text { th week }\end{array}$ & $\begin{array}{l}\downarrow \text { Mechanical (electronic mechanical } \\
\text { stimulator) and thermal (thermal paw } \\
\text { stimulator) hyperalgesia }\end{array}$ & & $\begin{array}{c}\text { Interacted perfectly with P2Y12 receptor } \\
\text { agonist-binding pocket } \\
\downarrow \text { mRNA and protein expressions of P2Y12 in } \\
\text { DRG } \\
\downarrow \text { Co-localization of glutamine synthetase (a } \\
\text { marker of SGCs) in DRG } \\
\downarrow \text { mRNA and protein expression of IL-1 } \beta \text { and } \\
\text { Cx43 expressions in DRG } \\
\text { X AKT activation }\end{array}$ & [28] \\
\hline \multicolumn{6}{|c|}{ Self-Nano Emulsifying Drug Delivery System (SNEDDS) Curcumin } \\
\hline Male Sprague-Dawley rats & $\begin{array}{c}\mathrm{STZ}-55 \mathrm{mg} / \mathrm{kg} \text {, i.p. } \\
\mathrm{STZ}+\text { naïve curcumin }(30,100 \text { and } \\
300 \mathrm{mg} / \mathrm{kg} \text {, oral, } 2 \text { weeks) } \\
\mathrm{STZ}+\mathrm{SNEDDS} \text { curcumin }(30,100 \text { and } \\
300 \mathrm{mg} / \mathrm{kg} \text {, oral, } 2 \text { weeks) }\end{array}$ & $\begin{array}{l}\text { O Body weight and plasma glucose level } \\
\checkmark \text { Thermal hyperalgesia (tail flick test) in } \\
\text { both hot and cold immersion } \\
\checkmark \text { Mechanical hyperalgesia (von Frey } \\
\text { and Randall Sellitto tests) }\end{array}$ & $\begin{array}{l}\text { Naïve and SNEDDS } \downarrow \\
\text { MNCV and NBF }\end{array}$ & $\begin{array}{c}\downarrow \text { MDA levels } \\
\text { SNEDDS } \downarrow \text { NF-kB protein expression } \\
\text { SNEDDS X IKK- } \beta \\
\text { phosphorylation expression } \\
\text { SNEDD } \downarrow \text { Protein expression of NF-kB } \\
\text { positive cells in nerves } \\
\text { SNEDDS } \downarrow \text { COX-2 and iNOS protein level } \\
\text { Naïve and SNEDDS } \downarrow \text { IL-6 level in } \\
\text { sciatic nerves } \\
\text { SNEDDS } \downarrow \text { TNF-a level in sciatic nerves }\end{array}$ & [30] \\
\hline \multicolumn{6}{|c|}{ h } \\
\hline \multicolumn{6}{|c|}{ Curcumin (Cur) Loaded with Lipid Nanocapsules (Cur@LNCs) } \\
\hline Female Sprague-Dawley rats & CCI + Cur@LNCs, $400 \mu \mathrm{L}$ inject, 7 days & $\downarrow$ Thermal hyperalgesia (hotplate) & & $\downarrow$ Sciatic nerve damages & [29] \\
\hline
\end{tabular}


Table 6. Cont.

\begin{tabular}{|c|c|c|c|c|c|}
\hline \multirow[b]{2}{*}{ Animals (Sex, Strain) } & \multirow{2}{*}{$\begin{array}{c}\text { Dose }(\mathrm{mg} / \mathrm{kg}) \text {, Route of } \\
\text { Administration, Duration of Treatment }\end{array}$} & \multicolumn{3}{|c|}{ Effects } & \multirow[b]{2}{*}{ Reference } \\
\hline & & $\begin{array}{l}\text { Behavioral Evaluation/ } \\
\text { Other Parameters }\end{array}$ & $\begin{array}{l}\text { Electrophysiological/ } \\
\text { Functional Evaluation }\end{array}$ & $\begin{array}{c}\text { Histopathological/ } \\
\text { Biochemical/Molecular Parameters }\end{array}$ & \\
\hline \multicolumn{6}{|c|}{ Curcumin Prodrug-Curcumin Diglutaric Acid } \\
\hline \multicolumn{6}{|c|}{ Curcumin-Loaded Poly (d, 1-lactide-co-glycolide) Nanovesicles } \\
\hline Male CD1 mice & $\begin{array}{c}\mathrm{CCI}+\text { curcumin }(20 \mathrm{mg} / \mathrm{kg} \text {, intravenous } \\
\text { or } 0.0005 \text { and } 0.025 \mathrm{mg} \text {, i.t. }) \\
\text { CCI }+ \text { PLGA } \\
\text { CUR }(0.045 \mathrm{mg} \text { curcumin } / \mathrm{mg} \text { of } \\
\text { nanoparticles, } 20 \mathrm{mg} / \mathrm{kg} \text {, intravenous }) \\
\text { CCI }+ \text { PLGA } \\
\text { CUR }(0.045 \mathrm{mg} \text { curcumin } / \mathrm{mg} \text { of } \\
\text { nanoparticles, } 0.0005 \text { and } 0.025 \mathrm{mg} \text {, i.t. })\end{array}$ & $\begin{array}{l}\text { Low and high PLGA-CUR, i.t. } \downarrow \\
\text { Mechanical allodynia (dynamic plantar } \\
\text { aesthesiometer test) and thermal } \\
\text { hyperalgesia (plantar test) } \\
\text { High curcumin, i.t. } \downarrow \text { allodynia } \\
\text { and hyperalgesia }\end{array}$ & & $\begin{array}{c}\text { High PLGA-CUR, i.t. } \downarrow \text { IL-1 } \beta, \text { IL-6,TNF- } \alpha \text { and } \\
\text { BDNF levels in spinal cord }\end{array}$ & [34] \\
\hline \multicolumn{6}{|c|}{ Curcumin Derivative } \\
\hline Male ICR mice & $\begin{array}{l}\text { Curcumin derivative KMS4034 (10 } \\
\text { mg/kg, i.p., } 120 \text { min post-injection) } \\
\text { In vitro: } 10 \mu \mathrm{M} \text { KMS4034 }\end{array}$ & $\uparrow$ Mechanical thresholds (von Frey) & $\begin{array}{l}\text { X ICAP and Iheat of } \\
\text { TRPV1-expressing } \\
\text { HEK293 cells }\end{array}$ & $\begin{array}{l}\downarrow \text { CGRP expression in lamina I-II of lumbar } \\
\text { dorsal horns }\end{array}$ & [31] \\
\hline
\end{tabular}

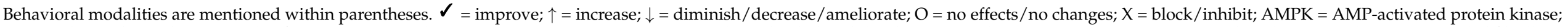

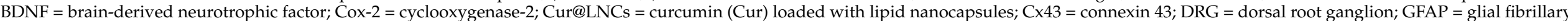

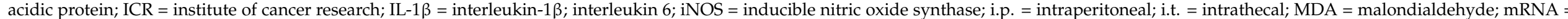

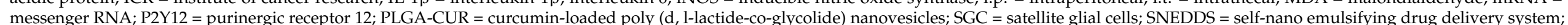
TNF- $\alpha=$ tumor necrosis factor alpha; NF- $\mathrm{kB}=$ nuclear factor kappa B; TNFR1 = tumor necrosis factor alpha receptor $1 ; \mathrm{TNFR} 2=$ tumor necrosis factor alpha receptor $2 ; \mathrm{TSPO}=$ translocator protein. 


\section{Curcumin and Its Formulations on Neuropathic Pain or Postoperative Pain-Clinical Studies}

A vast majority of the studies have reported the antioxidant and anti-inflammatory properties of curcumin and its formulations in clinical settings of chronic inflammatory joint pain, such as osteoarthritis and rheumatoid arthritis [200-208]. Only a few clinical studies have focused on the effects of curcumin and/or its formulations in PN and postoperative pain [209-215].

Table 7 summarizes the effects of curcumin on neuropathic pain and postoperative pain in clinical studies. Diabetic sensorimotor polyneuropathy (DSPN) is one of the most common complications in diabetes mellitus, resulting in impaired motor activity [216]. DSPN affects $25 \%$ of individuals with type 2 diabetes mellitus (T2DM) [217,218]. Asadi et al. [211] reported that nano curcumin supplementation decreased the total neuropathy score when assessed by the Toronto Clinical Neuropathy Score. The nano curcumin treatment also reduced the serum levels of fasting blood glucose (FBS) and HbA1c. The study also elucidated that DSPN can be improved by managing hyperglycemia in individuals with T2DM. In another study, patients treated with Meriva (lecithinized curcumin) showed significantly reduced chemotherapy-induced side effects, which was further confirmed by the semiquantitative evaluation of chemotherapy-induced side effects in the control group. Furthermore, patients treated with Meriva had reduced plasma levels of free radicals when compared to the control group [212]. Curcumin is also effective against chronic PN and pain induced by lumbar disc herniation and/or lumbar canal stenosis or carpal tunnel syndrome [215]. A multi-ingredient formula (800 mg dexibuprofen (Dex) + Lipicur (800 mg lipoic acid $+800 \mathrm{mg}$ curcumin phytosome $+8 \mathrm{mg}$ piperine), Dex $+800 \mathrm{mg}$ lipoic acid, and $800 \mathrm{mg}$ Dex only) reduced neuropathic pain in patients with lumbar sciatica and carpal tunnel syndrome. Curcumin efficiently reduced the use of dexibuprofen by $40 \%$, and add-on therapy with lipoic acid exerted no significant results, indicating that Lipicur could be used as an effective alternative therapeutic to treat neuropathic pain [215]. 
Table 7. Effects of curcumin on neuropathic pain and postoperative pain of clinical studies.

\begin{tabular}{|c|c|c|c|c|}
\hline \multirow{2}{*}{ Participants and Study Design } & \multirow{2}{*}{ Dose and Duration } & \multicolumn{2}{|l|}{ Effects } & \multirow{2}{*}{ Reference } \\
\hline & & Pain-Related & Other/Cardiometabolic & \\
\hline \multicolumn{5}{|c|}{ Diabetic Sensorimotor Polyneuropathy (DSPN) } \\
\hline $\begin{array}{c}\text { Patients with T2D }(n=80) ; \\
\text { RCT (placebo-controlled and double-blind) }\end{array}$ & $\begin{array}{l}\text { Nano curcumin }(72 \% \text { curcumin, } 80 \mathrm{mg}) \text { or } \\
\text { placebo capsules / day for eight weeks }\end{array}$ & $\begin{array}{l}\downarrow \text { Score of total neuropathies, reflex score, and } \\
\text { temperature in curcumin vs. placebo }\end{array}$ & $\begin{array}{l}\downarrow \mathrm{HbA1c} \text { and FBS in curcumin } \\
\text { vs. placebo }\end{array}$ & [211] \\
\hline \multicolumn{5}{|c|}{ Chemotherapy-Induced Peripheral Neuropathy (CIPN) } \\
\hline $\begin{array}{l}\text { Patients undergoing cancer chemo- and } \\
\text { radiotherapy }(n=160) ; \\
\text { RCT (placebo-controlled and double-blind) }\end{array}$ & $\begin{array}{l}\text { Lecithinized curcumin (Meriva: } 500 \mathrm{mg} \text { ) or } \\
\text { placebo for } 60 \text { days from first cycle of chemo- } \\
\text { or radiotherapy }\end{array}$ & $\begin{array}{l}\downarrow \text { Local pain rating based on VAS due to } \\
\text { radiotherapy in curcumin vs. placebo group }\end{array}$ & $\begin{array}{l}\downarrow \text { Chemotherapy side effects in } \\
\text { curcumin vs. placebo group }\end{array}$ & [212] \\
\hline \multicolumn{5}{|c|}{ Peripheral Neuropathy (PN) } \\
\hline $\begin{array}{c}\text { Patients with chronic PN and lumbar } \\
\text { disc herniation } \\
\text { and/or lumbar canal stenosis or carpal } \\
\text { tunnel syndrome; }(n=135) \\
\text { RCT, open }\end{array}$ & $\begin{array}{c}\text { Three formulations as follows: (1) Dex } \\
\text { (800 mg) + Lipicur [lipoic acid (800 mg) + } \\
\text { curcumin phytosome }(800 \mathrm{mg})+\text { piperine } \\
(8 \mathrm{mg})] ; \text { ( } 2) \text { Dex + lipoic acid (800 mg) and (3) } \\
\text { Dex only (800 mg) capsules / day for } \\
\text { eight weeks }\end{array}$ & $\begin{array}{c}\downarrow \text { Neuropathic pain in patients with lumbar } \\
\text { sciatica and carpal tunnel syndrome in } \\
\text { Lipicur group vs. others }\end{array}$ & $\begin{array}{l}\downarrow \text { Use of Dex in the Lipicur } \\
\text { group vs. others }\end{array}$ & [215] \\
\hline \multicolumn{5}{|c|}{$\begin{array}{ll}\text { Postoperative Pain } \\
\end{array}$} \\
\hline $\begin{array}{c}\text { Patients undergoing oral surgery for } \\
\text { periodontitis }(n=15) \\
\text { RCT (placebo-controlled) }\end{array}$ & $\begin{array}{l}\text { Curcumin mucoadhesive film }(0.5 \% \text { extract }) \\
\text { or placebo mucoadhesive film placed on } \\
\text { gingiva after surgery for seven days }\end{array}$ & $\begin{array}{l}\downarrow \text { Pain score rating and swelling in curcumin } \\
\text { vs. placebo group }\end{array}$ & $\begin{array}{l}\downarrow \text { Use of oral analgesics in } \\
\text { postoperative period in } \\
\text { curcumin vs. placebo group }\end{array}$ & [210] \\
\hline $\begin{array}{c}\text { Patients following laparoscopic gynecologic } \\
\text { surgery }(n=60) ; \\
\text { RCT, open }\end{array}$ & $\begin{array}{l}\text { Curcuminoids extract }(1000 \mathrm{mg}) \text { or standard } \\
\text { analgesia on postoperative days one to three }\end{array}$ & $\begin{array}{l}\downarrow \text { VAS pain scores following surgery in } \\
\text { curcumin vs. standard group }\end{array}$ & $\mathrm{N} / \mathrm{A}$ & [214] \\
\hline $\begin{array}{l}\text { Patients undergoing oral surgery for } \\
\text { impacted third molars }(n=90) \\
\text { RCT (placebo-controlled) }\end{array}$ & $\begin{array}{l}\text { Curcumin }(200 \mathrm{mg})+\text { amoxicillin }(500 \mathrm{mg}) \text { or } \\
\text { control (amoxicillin } 500 \mathrm{mg}+500 \mathrm{mg} \\
\text { mefenamic acid) three times for } 24 \mathrm{~h}\end{array}$ & $\begin{array}{l}\downarrow \text { Pain score rating in curcumin vs. } \\
\text { placebo group }\end{array}$ & $\mathrm{N} / \mathrm{A}$ & [213] \\
\hline $\begin{array}{c}\text { Patients undergoing laparoscopic } \\
\text { cholecystectomy }(n=50) ; \\
\text { RCT (placebo-controlled and double-blind) }\end{array}$ & $\begin{array}{c}\text { Curcumin }(500 \mathrm{mg}) \text { or placebo once every six } \\
\text { hours/day for three weeks }\end{array}$ & $\begin{array}{l}\downarrow \text { Pain score rating in curcumin vs. } \\
\text { placebo group }\end{array}$ & $\begin{array}{l}\downarrow \text { Fatigue score and the use of } \\
\text { oral analgesics in } \\
\text { postoperative period in } \\
\text { curcumin vs. placebo group }\end{array}$ & [209] \\
\hline
\end{tabular}

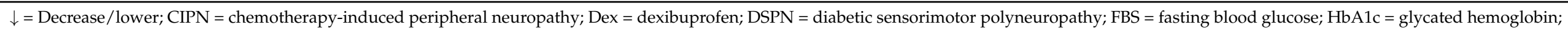

$\mathrm{N} / \mathrm{A}=$ not applicable; $\mathrm{PN}$ = peripheral neuropathy; $\mathrm{RCT}$ = randomized controlled trial; $\mathrm{T} 2 \mathrm{D}=$ type 2 diabetes; $\mathrm{VAS}=$ visual analog scale. 
In a pilot randomized trial, curcuminoids extracted from turmeric, containing curcumin, demethoxycurcumin, and bisdemethoxycurcumin [219], reduced postoperative pain severity after laparoscopic gynecologic surgery [214]. In another double-blinded, randomized, placebo-controlled study, curcumin not only reduced postoperative pain but also reduced fatigue based on the patient-reported outcomes following laparoscopic cholecystectomy [209]. Curcumin also reduced intensity of the acute postoperative pain followed by third molar extraction as evaluated by numeric rating scale [213]. Curcumin exerted better efficacy in reducing orofacial pain caused by the postoperative molar extraction-induced inflammation in comparison with mefenamic acid, a non-steroidal anti-inflammatory drug, commonly used to treat inflammatory pain [220-222]. Postsurgical removal of the third molar led to the upregulation of inflammatory cytokines, including interleukin 6 (IL-6) and interleukin 8, leading to the development of inflammatory pain [223]. Therefore, in their study, Maulina et al. [213] explained that curcumin demonstrated better anti-inflammatory activity by directly inhibiting the inflammatory cytokines as compared to mefenamic acid that indirectly inhibited or decreased IL-6 by suppressing the secretion of prostaglandin E2, responsible for inducing IL-6 expression [224]. The analgesic activity of curcumin against periodontal surgeries was further confirmed in another study in which curcumin mucoadhesive film reduced postoperative pain and swelling over a period of one week compared to the placebo mucoadhesive film. Therefore, the curcumin mucoadhesive film could become a commercially available phytochemical drug delivery system in the treatment of periodontal postsurgical pain [210]. Taken together, these aforementioned clinical studies conclude that curcumin and its formulations could be used as adjuvants for postoperative care.

\section{Conclusions}

The current review provides important information regarding the potential effects of curcumin in treating different peripheral neuropathic conditions, including alcoholic neuropathy, CCI-, CIPN-, DPN-, SNI-, and SNL-induced neuropathic and postoperative pain (Figure 4). Based on the present review, we identified a few drawbacks in both preclinical and clinical studies. First, only a handful studies have explored the effects of curcumin and its formulations in neuropathic and postoperative pain under clinical settings. Future studies should focus on conducting clinical studies on other PN pain conditions involving curcumin. Second, in most of the clinical studies only a single dose was used. Therefore, dose-related effects remain unknown. Third, only a few preclinical studies have compared the antinociceptive effects of curcumin with standard drugs. In order to enhance the application of curcumin in clinical treatment, it is important to administer clinically used drugs as experimental controls or for a reference comparison. Fourth, most of the animal studies evaluated the anti-hyperalgesic activity of curcumin either by monitoring the behavioral outcomes or by measuring the biochemical paraments. Besides these two parameters, the effects of curcumin on neuropathic pain should also be evaluated by monitoring functional recovery and electrophysiological aspects of pain conditions. Therefore, in the future, it is important to address the aforementioned shortcomings while designing both preclinical and clinical studies. In conclusion, with the advent of these new formulations, including curcuminoids, liposomal encapsulations, nanoparticles, derivatives, and analogs, the multifaceted favorable effects of curcumin will lead to the promising development of therapeutic agents for treating several neuropathic and postoperative pain conditions. 
I. Behavior

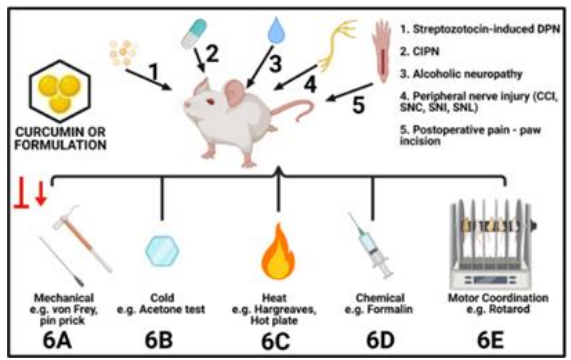

II. Electrophysiology/Histopathology

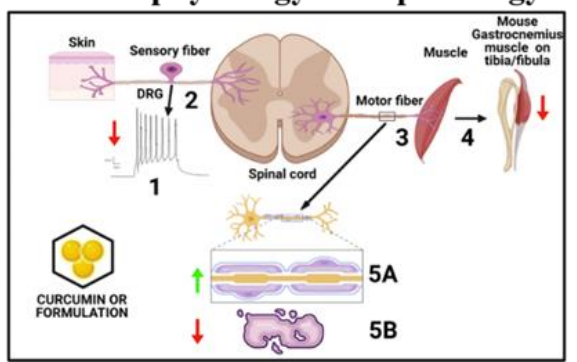

III. Molecular

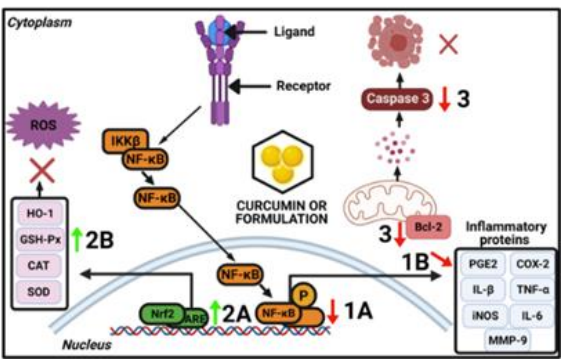

Figure 4. Effects on curcumin or its formulations at the behavior, electrophysiology/histopathology, and molecular levels in peripheral neuropathic and postoperative pain. I. Behavior: Curcumin or its formulations inhibit or reduce DPN (1), CIPN (2), alcoholic neuropathy (3), different peripheral injuries, such as CCI, SNC, SNI, SNL, etc., and/or postoperative paininduced behaviors in rodent models. Curcumin and its formulations mainly inhibit or reduce mechanical (6A), cold (6B), heat (6C), and chemical-induced (6D) pain behaviors, as well as motor deficits (6E). II. Electrophysiology/Histopathology: Curcumin or its formulations protect injured DRG, decrease neuronal excitability in DRG (1), resulting in attenuation of painful neuropathic behavior. Curcumin or its formulations increase SNCV, decrease loss of DRG neurons, and increase diameter of nerve fibers (2). Furthermore, curcumin and its formulations increase MNCV, decrease neurogenic lesions (3), and atrophy of gastrocnemius muscle (4). The treatments also effectively increase myelin sheath thickness (5A) and prevent demyelination (5B). III. Molecular: Curcumin or its formulations decrease expression of NF- $\mathrm{k}$, leading to decrease in inflammatory proteins. Furthermore, the treatments increase expressions of Nrf2, leading to increase in levels of antioxidative enzymes that scavenge free radicals and ultimately reduce ROS levels. Moreover, the treatments decrease expressions of Bcl-2 and caspase-3 that lead to reduction in apoptosis and ultimately improve nerve injuries (created with BioRender).

Author Contributions: P.B. and A.B. contributed to the conceptualization and literature review. P.B. prepared the original draft. P.B., C.M., and A.B. reviewed and edited the manuscript. All authors have read and agreed to the published version of the manuscript.

Funding: The research received no external funding.

Institutional Review Board Statement: Not applicable.

Informed Consent Statement: Not applicable.

Data Availability Statement: Not applicable.

Conflicts of Interest: The authors declare no conflict of interest.

\section{References}

1. Jensen, T.S.; Baron, R.; Haanpaa, M.; Kalso, E.; Loeser, J.D.; Rice, A.S.C.; Treede, R.D. A new definition of neuropathic pain. Pain 2011, 152, 2204-2205. [CrossRef]

2. Smith, B.H.; Torrance, N. Epidemiology of neuropathic pain and its impact on quality of life. Curr. Pain Headache Rep. 2012, 16, 191-198. [CrossRef] [PubMed]

3. Meacham, K.; Shepherd, A.; Mohapatra, D.P.; Haroutounian, S. Neuropathic pain: Central vs. Peripheral mechanisms. Curr. Pain Headache Rep. 2017, 21, 28. [CrossRef] [PubMed]

4. Cavalli, E.; Mammana, S.; Nicoletti, F.; Bramanti, P.; Mazzon, E. The neuropathic pain: An overview of the current treatment and future therapeutic approaches. Int. J. Immunopathol. Pharmacol. 2019, 33, 2058738419838383. [CrossRef] [PubMed]

5. Kehlet, H.; Jensen, T.S.; Woolf, C.J. Persistent postsurgical pain: Risk factors and prevention. Lancet 2006, 367, 1618-1625. [CrossRef]

6. Ramsay, M.A. Acute postoperative pain management. Proc. Bayl. Univ. Med. Cent. 2000, 13, 244-247. [CrossRef] [PubMed]

7. Koppert, W.; Schmelz, M. The impact of opioid-induced hyperalgesia for postoperative pain. Best Pract. Res. Clin. Anaesthesiol. 2007, 21, 65-83. [CrossRef]

8. Benyamin, R.; Trescot, A.M.; Datta, S.; Buenaventura, R.; Adlaka, R.; Sehgal, N.; Glaser, S.E.; Vallejo, R. Opioid complications and side effects. Pain Physician 2008, 11 (Suppl. 2), S105-S120. [CrossRef]

9. Barletta, J.F.; Asgeirsson, T.; Senagore, A.J. Influence of intravenous opioid dose on postoperative ileus. Ann. Pharmacother. 2011, 45, 916-923. [CrossRef]

10. Goettsch, W.G.; Sukel, M.P.P.; van der Peet, D.L.; van Riemsdijk, M.M.; Herings, R.M.C. In-hospital use of opioids increases rate of coded postoperative paralytic ileus. Pharmacoepidemiol. Drug Saf. 2007, 16, 668-674. [CrossRef] 
11. Quintans, J.S.; Antoniolli, A.R.; Almeida, J.R.; Santana-Filho, V.J.; Quintans-Junior, L.J. Natural products evaluated in neuropathic pain models-A systematic review. Basic Clin. Pharmacol. Toxicol. 2014, 114, 442-450. [CrossRef]

12. Basu, P.; Basu, A. In vitro and in vivo effects of flavonoids on peripheral neuropathic pain. Molecules 2020, 25, 1171. [CrossRef] [PubMed]

13. Lim, E.Y.; Kim, Y.T. Food-derived natural compounds for pain relief in neuropathic pain. BioMed Res. Int. 2016, $2016,7917528$. [CrossRef] [PubMed]

14. Forouzanfar, F.; Hosseinzadeh, H. Medicinal herbs in the treatment of neuropathic pain: A review. Iran. J. Basic Med. Sci. 2018, 21, 347-358.

15. Boadas-Vaello, P.; Vela, J.M.; Verdu, E. New pharmacological approaches using polyphenols on the physiopathology of neuropathic pain. Curr. Drug Targets 2017, 18, 160-173. [CrossRef] [PubMed]

16. Smejkal, K. Selected natural phenolic compounds-Potential treatment for peripheral neuropathy? Ceska Slov. Farm. 2014, 63, 55-70. [PubMed]

17. Alghamdi, S. Antinociceptive effect of the citrus flavonoid eriocitrinon postoperative pain conditions. J. Pain Res. 2020, 13, 805-815. [CrossRef]

18. Park, K.M.; Kim, J.H. Herbal medicine for the management of postoperative pain: A protocol for the systematic review of randomized controlled trials. Medicine 2019, 98, e14016. [CrossRef]

19. Lee, W.H.; Loo, C.Y.; Bebawy, M.; Luk, F.; Mason, R.S.; Rohanizadeh, R. Curcumin and its derivatives: Their application in neuropharmacology and neuroscience in the 21st century. Curr. Neuropharmacol. 2013, 11, 338-378. [CrossRef] [PubMed]

20. Menon, V.P.; Sudheer, A.R. Antioxidant and anti-inflammatory properties of curcumin. Adv. Exp. Med. Biol. 2007, 595, 105-125.

21. Hewlings, S.J.; Kalman, D.S. Curcumin: A review of its effects on human health. Foods 2017, 6, 92. [CrossRef]

22. Cheppudira, B.; Fowler, M.; McGhee, L.; Greer, A.; Mares, A.; Petz, L.; Devore, D.; Loyd, D.R.; Clifford, J.L. Curcumin: A novel therapeutic for burn pain and wound healing. Expert Opin. Investig. Drugs 2013, 22, 1295-1303. [CrossRef] [PubMed]

23. Eke-Okoro, U.J.; Raffa, R.B.; Pergolizzi, J.V., Jr.; Breve, F.; Taylor, R., Jr.; NEMA Research Group. Curcumin in turmeric: Basic and clinical evidence for a potential role in analgesia. J. Clin. Pharm. 2018, 43,460-466. [CrossRef]

24. Caillaud, M.; Aung Myo, Y.P.; McKiver, B.D.; Osinska Warncke, U.; Thompson, D.; Mann, J.; Del Fabbro, E.; Desmouliere, A.; Billet, F.; Damaj, M.I. Key developments in the potential of curcumin for the treatment of peripheral neuropathies. Antioxidants 2020, 9, 950. [CrossRef]

25. Sun, J.; Chen, F.; Braun, C.; Zhou, Y.Q.; Rittner, H.; Tian, Y.K.; Cai, X.Y.; Ye, D.W. Role of curcumin in the management of pathological pain. Phytomedicine 2018, 48, 129-140. [CrossRef] [PubMed]

26. Nistico, S.; Tamburi, F.; Bennardo, L.; Dastoli, S.; Schipani, G.; Caro, G.; Fortuna, M.C.; Rossi, A. Treatment of telogen effluvium using a dietary supplement containing boswellia serrata, curcuma longa, and vitis vinifera: Results of an observational study. Dermatol. Ther. 2019, 32, e12842. [CrossRef] [PubMed]

27. Daugherty, D.J.; Marquez, A.; Calcutt, N.A.; Schubert, D. A novel curcumin derivative for the treatment of diabetic neuropathy. Neuropharmacology 2018, 129, 26-35. [CrossRef] [PubMed]

28. Jia, T.; Rao, J.; Zou, L.; Zhao, S.; Yi, Z.; Wu, B.; Li, L.; Yuan, H.; Shi, L.; Zhang, C.; et al. Nanoparticle-encapsulated curcumin inhibits diabetic neuropathic pain involving the p2y12 receptor in the dorsal root ganglia. Front. Neurosci. 2017, 11, 755. [CrossRef] [PubMed]

29. Jiang, X.; Wang, S.; Chen, H. A novel fabrication of dose-dependent injectable curcumin biocomposite hydrogel system anesthetic delivery method for care and management of musculoskeletal pain. Dose Response 2020, 18, 1559325820929555. [CrossRef] [PubMed]

30. Joshi, R.P.; Negi, G.; Kumar, A.; Pawar, Y.B.; Munjal, B.; Bansal, A.K.; Sharma, S.S. Snedds curcumin formulation leads to enhanced protection from pain and functional deficits associated with diabetic neuropathy: An insight into its mechanism for neuroprotection. Nanomedicine 2013, 9, 776-785. [CrossRef] [PubMed]

31. Lee, J.Y.; Shin, T.J.; Choi, J.M.; Seo, K.S.; Kim, H.J.; Yoon, T.G.; Lee, Y.S.; Han, H.; Chung, H.J.; Oh, Y.; et al. Antinociceptive curcuminoid, kms4034, effects on inflammatory and neuropathic pain likely via modulating trpv1 in mice. Br. J. Anaesth. 2013, 111, 667-672. [CrossRef]

32. Limcharoen, T.; Dasuni Wasana, P.W.; Hasriadi; Muangnoi, C.; Vajragupta, O.; Rojsitthisak, P.; Towiwat, P. Curcumin diglutaric acid, a prodrug of curcumin reduces pain hypersensitivity in chronic constriction injury of sciatic nerve induced-neuropathy in mice. Pharmaceuticals 2020, 13, 212. [CrossRef] [PubMed]

33. Lv, J.; Cao, L.; Zhang, R.; Bai, F.; Wei, P. A curcumin derivative j147 ameliorates diabetic peripheral neuropathy in streptozotocin (stz)-induced dpn rat models through negative regulation ampk on trpa1. Acta Cirúrgica Bras. 2018, 33, 533-541. [CrossRef] [PubMed]

34. Pieretti, S.; Ranjan, A.P.; Di Giannuario, A.; Mukerjee, A.; Marzoli, F.; Di Giovannandrea, R.; Vishwanatha, J.K. Curcumin-loaded poly (d, l-lactide-co-glycolide) nanovesicles induce antinociceptive effects and reduce pronociceptive cytokine and bdnf release in spinal cord after acute administration in mice. Colloids Surf. B Biointerface 2017, 158, 379-386. [CrossRef] [PubMed]

35. McClements, D.J.; Decker, E.A.; Park, Y.; Weiss, J. Structural design principles for delivery of bioactive components in nutraceuticals and functional foods. Crit. Rev. Food Sci. Nutr. 2009, 49, 577-606. [CrossRef] [PubMed]

36. McClements, D.J.; Decker, E.A.; Weiss, J. Emulsion-based delivery systems for lipophilic bioactive components. J. Food Sci. 2007, 72, R109-R124. [CrossRef] 
37. Nabavi, S.F.; Daglia, M.; Moghaddam, A.H.; Habtemariam, S.; Nabavi, S.M. Curcumin and liver disease: From chemistry to medicine. Compr. Rev. Food Sci. Food Saf. 2014, 13, 62-77. [CrossRef]

38. Vyas, A.; Dandawate, P.; Padhye, S.; Ahmad, A.; Sarkar, F. Perspectives on new synthetic curcumin analogs and their potential anticancer properties. Curr. Pharm. Des. 2013, 19, 2047-2069.

39. Aggarwal, B.B.; Deb, L.; Prasad, S. Curcumin differs from tetrahydrocurcumin for molecular targets, signaling pathways and cellular responses. Molecules 2014, 20, 185-205. [CrossRef]

40. Farombi, E.O.; Shrotriya, S.; Na, H.-K.; Kim, S.-H.; Surh, Y.-J. Curcumin attenuates dimethylnitrosamine-induced liver injury in rats through nrf2-mediated induction of heme oxygenase-1. Food Chem. Toxicol. 2008, 46, 1279-1287. [CrossRef]

41. Anand, P.; Thomas, S.G.; Kunnumakkara, A.B.; Sundaram, C.; Harikumar, K.B.; Sung, B.; Tharakan, S.T.; Misra, K.; Priyadarsini, I.K.; Rajasekharan, K.N.; et al. Biological activities of curcumin and its analogues (congeners) made by man and mother nature. Biochem. Pharmacol. 2008, 76, 1590-1611. [CrossRef] [PubMed]

42. Hazra, M.K.; Roy, S.; Bagchi, B. Hydrophobic hydration driven self-assembly of curcumin in water: Similarities to nucleation and growth under large metastability, and an analysis of water dynamics at heterogeneous surfaces. J. Chem. Phys. 2014, 141, 18C501. [CrossRef] [PubMed]

43. Kolev, T.M.; Velcheva, E.A.; Stamboliyska, B.A.; Spiteller, M. Dft and experimental studies of the structure and vibrational spectra of curcumin. Int. J. Quantum Chem. 2005, 102, 1069-1079. [CrossRef]

44. Ravindran, P.; Babu, K.N.; Sivaraman, K. Turmeric: The Genus Curcuma; CRC Press: Boca Raton, FL, USA, 2007.

45. Stanić, Z. Curcumin, a compound from natural sources, a true scientific challenge-A review. Plant Foods Hum. Nutr. 2017, 72, 1-12. [CrossRef]

46. Jayaprakasha, G.; Rao, L.J.M.; Sakariah, K. Chemistry and biological activities of c. Longa. Trends Food Sci. Technol. 2005, 16, 533-548. [CrossRef]

47. Itokawa, H.; Shi, Q.; Akiyama, T.; Morris-Natschke, S.L.; Lee, K.-H. Recent advances in the investigation of curcuminoids. Chin. Med. 2008, 3, 1-13. [CrossRef] [PubMed]

48. Heger, M.; van Golen, R.F.; Broekgaarden, M.; Michel, M.C. The molecular basis for the pharmacokinetics and pharmacodynamics of curcumin and its metabolites in relation to cancer. Pharm. Rev. 2014, 66, 222-307. [CrossRef]

49. Luca, S.V.; Macovei, I.; Bujor, A.; Miron, A.; Skalicka-Wozniak, K.; Aprotosoaie, A.C.; Trifan, A. Bioactivity of dietary polyphenols: The role of metabolites. Crit. Rev. Food Sci. Nutr. 2020, 60, 626-659. [CrossRef]

50. Pan, M.-H.; Huang, T.-M.; Lin, J.-K. Biotransformation of curcumin through reduction and glucuronidation in mice. Drug Metab. Dispos. 1999, 27, 486-494.

51. Ireson, C.; Orr, S.; Jones, D.J.L.; Verschoyle, R.; Lim, C.-K.; Luo, J.-L.; Howells, L.; Plummer, S.; Jukes, R.; Williams, M.; et al. Characterization of metabolites of the chemopreventive agent curcumin in human and rat hepatocytes and in the rat in vivo, and evaluation of their ability to inhibit phorbol ester-induced prostaglandin $E_{2}$ production. Cancer Res. 2001, 61, 1058-1064.

52. Asai, A.; Miyazawa, T. Occurrence of orally administered curcuminoid as glucuronide and glucuronide/sulfate conjugates in rat plasma. Life Sci. 2000, 67, 2785-2793. [CrossRef]

53. Esatbeyoglu, T.; Huebbe, P.; Ernst, I.M.A.; Chin, D.; Wagner, A.E.; Rimbach, G. Curcumin—From molecule to biological function. Angew. Chem. Int. Ed. 2012, 51, 5308-5332. [CrossRef] [PubMed]

54. Anand, P.; Kunnumakkara, A.B.; Newman, R.A.; Aggarwal, B.B. Bioavailability of curcumin: Problems and promises. Mol. Pharm. 2007, 4, 807-818. [CrossRef] [PubMed]

55. Begum, A.N.; Jones, M.R.; Lim, G.P.; Morihara, T.; Kim, P.; Heath, D.D.; Rock, C.L.; Pruitt, M.A.; Yang, F.; Hudspeth, B.; et al. Curcumin structure-function, bioavailability, and efficacy in models of neuroinflammation and alzheimer's disease. J. Pharmacol. Exp. Ther. 2008, 326, 196-208. [CrossRef] [PubMed]

56. Yang, K.-Y.; Lin, L.-C.; Tseng, T.-Y.; Wang, S.-C.; Tsai, T.-H. Oral bioavailability of curcumin in rat and the herbal analysis from curcuma longa by lc-ms/ms. J. Chromatogr. B 2007, 853, 183-189. [CrossRef]

57. Nelson, K.M.; Dahlin, J.L.; Bisson, J.; Graham, J.; Pauli, G.F.; Walters, M.A. The essential medicinal chemistry of curcumin. J. Med. Chem. 2017, 60, 1620-1637. [CrossRef]

58. Prasad, S.; Tyagi, A.K.; Aggarwal, B.B. Recent developments in delivery, bioavailability, absorption and metabolism of curcumin: The golden pigment from golden spice. Cancer Res. Treat. 2014, 46, 2-18. [CrossRef]

59. Douglass, B.J.; Clouatre, D.L. Beyond yellow curry: Assessing commercial curcumin absorption technologies. J. Am. Coll. Nutr. 2015, 34, 347-358. [CrossRef]

60. Stohs, S.J.; Ji, J.; Bucci, L.R.; Preuss, H.G. A comparative pharmacokinetic assessment of a novel highly bioavailable curcumin formulation with 95\% curcumin: A randomized, double-blind, crossover study. J. Am. Coll. Nutr. 2018, 37, 51-59. [CrossRef]

61. Vareed, S.K.; Kakarala, M.; Ruffin, M.T.; Crowell, J.A.; Normolle, D.P.; Djuric, Z.; Brenner, D.E. Pharmacokinetics of curcumin conjugate metabolites in healthy human subjects. Cancer Epidemiol. Biomark. Prev. 2008, 17, 1411-1417. [CrossRef] [PubMed]

62. Hassaninasab, A.; Hashimoto, Y.; Tomita-Yokotani, K.; Kobayashi, M. Discovery of the curcumin metabolic pathway involving a unique enzyme in an intestinal microorganism. Proc. Natl. Acad. Sci. USA 2011, 108, 6615-6620. [CrossRef] [PubMed]

63. Cheng, A.L.; Hsu, C.H.; Lin, J.K.; Hsu, M.M.; Ho, Y.F.; Shen, T.S.; Ko, J.Y.; Lin, J.T.; Lin, B.R.; Ming-Shiang, W.; et al. Phase i clinical trial of curcumin, a chemopreventive agent, in patients with high-risk or pre-malignant lesions. Anticancer Res. 2001, 21, 2895-2900. [PubMed] 
64. Dei Cas, M.; Ghidoni, R. Dietary curcumin: Correlation between bioavailability and health potential. Nutrients 2019, 11, 2147. [CrossRef]

65. Schiborr, C.; Eckert, G.P.; Rimbach, G.; Frank, J. A validated method for the quantification of curcumin in plasma and brain tissue by fast narrow-bore high-performance liquid chromatography with fluorescence detection. Anal. Bioanal. Chem. 2010, 397, 1917-1925. [CrossRef]

66. Chang, M.-T.; Tsai, T.-R.; Lee, C.-Y.; Wei, Y.-S.; Chen, Y.-J.; Chen, C.-R.; Tzen, J.T.C. Elevating bioavailability of curcumin via encapsulation with a novel formulation of artificial oil bodies. J. Agric. Food Chem. 2013, 61, 9666-9671. [CrossRef] [PubMed]

67. Lao, C.D.; Ruffin, M.T.T.; Normolle, D.; Heath, D.D.; Murray, S.I.; Bailey, J.M.; Boggs, M.E.; Crowell, J.; Rock, C.L.; Brenner, D.E. Dose escalation of a curcuminoid formulation. BMC Complement. Altern. Med. 2006, 6, 10. [CrossRef] [PubMed]

68. Sharma, R.A.; Euden, S.A.; Platton, S.L.; Cooke, D.N.; Shafayat, A.; Hewitt, H.R.; Marczylo, T.H.; Morgan, B.; Hemingway, D.; Plummer, S.M.; et al. Phase i clinical trial of oral curcumin. Biomark. Syst. Act. Compliance 2004, 10, 6847-6854.

69. Ringman, J.M.; Frautschy, S.A.; Teng, E.; Begum, A.N.; Bardens, J.; Beigi, M.; Gylys, K.H.; Badmaev, V.; Heath, D.D.; Apostolova, L.G.; et al. Oral curcumin for alzheimer's disease: Tolerability and efficacy in a 24-week randomized, double blind, placebocontrolled study. Alzheimers Res. Ther. 2012, 4, 43. [CrossRef] [PubMed]

70. Mahale, J.; Singh, R.; Howells, L.M.; Britton, R.G.; Khan, S.M.; Brown, K. Detection of plasma curcuminoids from dietary intake of turmeric-containing food in human volunteers. Mol. Nutr. Food Res. 2018, 62, 1800267. [CrossRef] [PubMed]

71. Kanai, M.; Yoshimura, K.; Asada, M.; Imaizumi, A.; Suzuki, C.; Matsumoto, S.; Nishimura, T.; Mori, Y.; Masui, T.; Kawaguchi, Y.; et al. A phase $\mathrm{i} /$ ii study of gemcitabine-based chemotherapy plus curcumin for patients with gemcitabine-resistant pancreatic cancer. Cancer Chemother. Pharmacol. 2011, 68, 157-164. [CrossRef] [PubMed]

72. Yerdelen, D.; Koc, F.; Uysal, H. Strength-duration properties of sensory and motor axons in alcoholic polyneuropathy. Neurol. Res. 2008, 30, 746-750. [CrossRef]

73. Koike, H.; Iijima, M.; Sugiura, M.; Mori, K.; Hattori, N.; Ito, H.; Hirayama, M.; Sobue, G. Alcoholic neuropathy is clinicopathologically distinct from thiamine-deficiency neuropathy. Ann. Neurol. 2003, 54, 19-29. [CrossRef]

74. Koike, H.; Sobue, G. Alcoholic neuropathy. Curr. Opin. Neurol. 2006, 19, 481-486. [CrossRef] [PubMed]

75. Bosch, E.P.; Pelham, R.W.; Rasool, C.G.; Chatterjee, A.; Lash, R.W.; Brown, L.; Munsat, T.L.; Bradley, W.G. Animal models of alcoholic neuropathy: Morphologic, electrophysiologic, and biochemical findings. Muscle Nerve 1979, 2, 133-144. [CrossRef] [PubMed]

76. Monforte, R.; Estruch, R.; Valls-Sole, J.; Nicolas, J.; Villalta, J.; Urbano-Marquez, A. Autonomic and peripheral neuropathies in patients with chronic alcoholism. A dose-related toxic effect of alcohol. Arch. Neurol. 1995, 52, 45-51. [CrossRef]

77. Palliyath, S.; Schwartz, B.D. Peripheral nerve functions improve in chronic alcoholic patients on abstinence. J. Stud. Alcohol 1993, 54, 684-686. [CrossRef]

78. McDonough, K.H. Antioxidant nutrients and alcohol. Toxicology 2003, 189, 89-97. [CrossRef]

79. Montoliu, C.; Valles, S.; Renau-Piqueras, J.; Guerri, C. Ethanol-induced oxygen radical formation and lipid peroxidation in rat brain: Effect of chronic alcohol consumption. J. Neurochem. 1994, 63, 1855-1862. [CrossRef] [PubMed]

80. Kandhare, A.D.; Raygude, K.S.; Ghosh, P.; Ghule, A.E.; Bodhankar, S.L. Therapeutic role of curcumin in prevention of biochemical and behavioral aberration induced by alcoholic neuropathy in laboratory animals. Neurosci. Lett. 2012, 511, 18-22. [CrossRef] [PubMed]

81. Huang, L.J.; Yoon, M.H.; Choi, J.I.; Kim, W.M.; Lee, H.G.; Kim, Y.O. Effect of sildenafil on neuropathic pain and hemodynamics in rats. Yonsei Med. J. 2010, 51, 82-87. [CrossRef] [PubMed]

82. Wang, L.; Chopp, M.; Szalad, A.; Jia, L.; Lu, X.; Lu, M.; Zhang, L.; Zhang, Y.; Zhang, R.; Zhang, Z.G. Sildenafil ameliorates long term peripheral neuropathy in type ii diabetic mice. PLOS ONE 2015, 10, e0118134. [CrossRef]

83. Kaur, M.; Singh, A.; Kumar, B.; Singh, S.K.; Bhatia, A.; Gulati, M.; Prakash, T.; Bawa, P.; Malik, A.H. Protective effect of co-administration of curcumin and sildenafil in alcohol induced neuropathy in rats. Eur. J. Pharmacol. 2017, 805, 58-66. [CrossRef] [PubMed]

84. Yardim, A.; Kandemir, F.M.; Comakli, S.; Ozdemir, S.; Caglayan, C.; Kucukler, S.; Celik, H. Protective effects of curcumin against paclitaxel-induced spinal cord and sciatic nerve injuries in rats. Neurochem. Res. 2020, 46, 379-395. [CrossRef]

85. Zhang, X.; Guan, Z.; Wang, X.; Sun, D.; Wang, D.; Li, Y.; Pei, B.; Ye, M.; Xu, J.; Yue, X. Curcumin alleviates oxaliplatin-induced peripheral neuropathic pain through inhibiting oxidative stress-mediated activation of $\mathrm{nf}-\mathrm{kb}$ and mitigating inflammation. Biol. Pharm. Bull. 2020, 43, 348-355. [CrossRef] [PubMed]

86. Agthong, S.; Kaewsema, A.; Charoensub, T. Curcumin ameliorates functional and structural abnormalities in cisplatin-induced neuropathy. Exp. Neurobiol. 2015, 24, 139-145. [CrossRef] [PubMed]

87. Babu, A.; Prasanth, K.G.; Balaji, B. Effect of curcumin in mice model of vincristine-induced neuropathy. Pharm. Biol. 2015, 53, 838-848. [CrossRef] [PubMed]

88. Al Moundhri, M.S.; Al-Salam, S.; Al Mahrouqee, A.; Beegam, S.; Ali, B.H. The effect of curcumin on oxaliplatin and cisplatin neurotoxicity in rats: Some behavioral, biochemical, and histopathological studies. J. Med. Toxicol. 2013, 9, 25-33. [CrossRef] [PubMed]

89. Abd Allah, E.S.H.; Gomaa, A.M.S. Effects of curcumin and captopril on the functions of kidney and nerve in streptozotocininduced diabetic rats: Role of angiotensin converting enzyme 1. Appl. Physiol. Nutr. Metab. 2015, 40, 1061-1067. [CrossRef] 
90. Meng, B.; Shen, L.L.; Shi, X.T.; Gong, Y.S.; Fan, X.F.; Li, J.; Cao, H. Effects of curcumin on ttx-r sodium currents of dorsal root ganglion neurons in type 2 diabetic rats with diabetic neuropathic pain. Neurosci. Lett. 2015, 605, 59-64. [CrossRef]

91. Banafshe, H.R.; Hamidi, G.A.; Noureddini, M.; Mirhashemi, S.M.; Mokhtari, R.; Shoferpour, M. Effect of curcumin on diabetic peripheral neuropathic pain: Possible involvement of opioid system. Eur. J. Pharmacol. 2014, 723, 202-206. [CrossRef]

92. Zhao, W.C.; Zhang, B.; Liao, M.J.; Zhang, W.X.; He, W.Y.; Wang, H.B.; Yang, C.X. Curcumin ameliorated diabetic neuropathy partially by inhibition of nadph oxidase mediating oxidative stress in the spinal cord. Neurosci. Lett. 2014, 560, 81-85. [CrossRef] [PubMed]

93. Li, Y.; Zhang, Y.; Liu, D.B.; Liu, H.Y.; Hou, W.G.; Dong, Y.S. Curcumin attenuates diabetic neuropathic pain by downregulating tnf-alpha in a rat model. Int. J. Med. Sci. 2013, 10, 377-381. [CrossRef]

94. Acar, A.; Akil, E.; Alp, H.; Evliyaoglu, O.; Kibrisli, E.; Inal, A.; Unan, F.; Tasdemir, N. Oxidative damage is ameliorated by curcumin treatment in brain and sciatic nerve of diabetic rats. Int. J. Neurosci. 2012, 122, 367-372. [CrossRef] [PubMed]

95. Sharma, S.; Kulkarni, S.K.; Agrewala, J.N.; Chopra, K. Curcumin attenuates thermal hyperalgesia in a diabetic mouse model of neuropathic pain. Eur. J. Pharmacol. 2006, 536, 256-261. [CrossRef] [PubMed]

96. Attia, H.N.; Al-Rasheed, N.M.; Al-Rasheed, N.M.; Maklad, Y.A.; Ahmed, A.A.; Kenawy, S.A. Protective effects of combined therapy of gliclazide with curcumin in experimental diabetic neuropathy in rats. Behav. Pharmacol. 2012, 23, 153-161. [CrossRef] [PubMed]

97. Sharma, S.; Chopra, K.; Kulkarni, S.K. Effect of insulin and its combination with resveratrol or curcumin in attenuation of diabetic neuropathic pain: Participation of nitric oxide and tnf-alpha. Phytother. Res. 2007, 21, 278-283. [CrossRef] [PubMed]

98. Kaley, T.J.; Deangelis, L.M. Therapy of chemotherapy-induced peripheral neuropathy. Br. J. Haematol. 2009, 145, 3-14. [CrossRef] [PubMed]

99. Verstappen, C.C.; Koeppen, S.; Heimans, J.J.; Huijgens, P.C.; Scheulen, M.E.; Strumberg, D.; Kiburg, B.; Postma, T.J. Dose-related vincristine-induced peripheral neuropathy with unexpected off-therapy worsening. Neurology 2005, 64, 1076-1077. [CrossRef] [PubMed]

100. Gutierrez-Gutierrez, G.; Sereno, M.; Miralles, A.; Casado-Saenz, E.; Gutierrez-Rivas, E. Chemotherapy-induced peripheral neuropathy: Clinical features, diagnosis, prevention and treatment strategies. Clin. Transl. Oncol. 2010, 12, 81-91. [CrossRef] [PubMed]

101. Duggett, N.A.; Griffiths, L.A.; McKenna, O.E.; de Santis, V.; Yongsanguanchai, N.; Mokori, E.B.; Flatters, S.J. Oxidative stress in the development, maintenance and resolution of paclitaxel-induced painful neuropathy. Neuroscience 2016, 333, 13-26. [CrossRef]

102. Duggett, N.A.; Griffiths, L.A.; Flatters, S.J.L. Paclitaxel-induced painful neuropathy is associated with changes in mitochondrial bioenergetics, glycolysis, and an energy deficit in dorsal root ganglia neurons. Pain 2017, 158, 1499-1508. [CrossRef] [PubMed]

103. Gong, S.S.; Li, Y.X.; Zhang, M.T.; Du, J.; Ma, P.S.; Yao, W.X.; Zhou, R.; Niu, Y.; Sun, T.; Yu, J.Q. Neuroprotective effect of matrine in mouse model of vincristine-induced neuropathic pain. Neurochem. Res. 2016, 41, 3147-3159. [CrossRef] [PubMed]

104. Khasabova, I.A.; Khasabov, S.G.; Olson, J.K.; Uhelski, M.L.; Kim, A.H.; Albino-Ramirez, A.M.; Wagner, C.L.; Seybold, V.S.; Simone, D.A. Pioglitazone, a ppargamma agonist, reduces cisplatin-evoked neuropathic pain by protecting against oxidative stress. Pain 2019, 160, 688-701. [CrossRef] [PubMed]

105. Bennett, G.J.; Doyle, T.; Salvemini, D. Mitotoxicity in distal symmetrical sensory peripheral neuropathies. Nat. Rev. Neurol. 2014, 10, 326-336. [CrossRef] [PubMed]

106. Toyama, S.; Shimoyama, N.; Szeto, H.H.; Schiller, P.W.; Shimoyama, M. Protective effect of a mitochondria-targeted peptide against the development of chemotherapy-induced peripheral neuropathy in mice. ACS Chem. Neurosci. 2018, 9, 1566-1571. [CrossRef] [PubMed]

107. Janes, K.; Doyle, T.; Bryant, L.; Esposito, E.; Cuzzocrea, S.; Ryerse, J.; Bennett, G.J.; Salvemini, D. Bioenergetic deficits in peripheral nerve sensory axons during chemotherapy-induced neuropathic pain resulting from peroxynitrite-mediated post-translational nitration of mitochondrial superoxide dismutase. Pain 2013, 154, 2432-2440. [CrossRef] [PubMed]

108. Areti, A.; Yerra, V.G.; Naidu, V.; Kumar, A. Oxidative stress and nerve damage: Role in chemotherapy induced peripheral neuropathy. Redox Biol. 2014, 2, 289-295. [CrossRef]

109. Fukuda, Y.; Li, Y.; Segal, R.A. A mechanistic understanding of axon degeneration in chemotherapy-induced peripheral neuropathy. Front. Neurosci. 2017, 11, 481. [CrossRef]

110. Carvalho, L.F.; Silva, A.M.F.; Carvalho, A.A. The use of antioxidant agents for chemotherapy-induced peripheral neuropathy treatment in animal models. Clin. Exp. Pharmacol. Physiol. 2017, 44, 971-979. [CrossRef] [PubMed]

111. Matsuoka, A.; Mitsuma, A.; Maeda, O.; Kajiyama, H.; Kiyoi, H.; Kodera, Y.; Nagino, M.; Goto, H.; Ando, Y. Quantitative assessment of chemotherapy-induced peripheral neurotoxicity using a point-of-care nerve conduction device. Cancer Sci. 2016, 107, 1453-1457. [CrossRef]

112. Nguyen, M.T.; Hua, C.L.; Sun, N.; Brown, J.S. Miami university background an estimated 30.3 million people in the united states, or $9.4 \%$ of the national population, have diabetes (cdc, 2017). In Diabetes is Associated with Increased Morbidity; Miami University: Oxford, OH, USA, 2017.

113. Barrett, A.M.; Lucero, M.A.; Le, T.; Robinson, R.L.; Dworkin, R.H.; Chappell, A.S. Epidemiology, public health burden, and treatment of diabetic peripheral neuropathic pain: A review. Pain Med. 2007, 8 (Suppl. 2), S50-S62. [CrossRef]

114. Tesfaye, S.; Selvarajah, D. Advances in the epidemiology, pathogenesis and management of diabetic peripheral neuropathy. Diabetes Metab. Res. Rev. 2012, 28 (Suppl. 1), 8-14. [CrossRef] 
115. Kaur, S.; Pandhi, P.; Dutta, P. Painful diabetic neuropathy: An update. Ann. Neurosci. 2011, 18, 168-175. [CrossRef]

116. Tesfaye, S.; Boulton, A.J.; Dickenson, A.H. Mechanisms and management of diabetic painful distal symmetrical polyneuropathy. Diabetes Care 2013, 36, 2456-2465. [CrossRef]

117. Harati, Y. Diabetic neuropathies: Unanswered questions. Neurol. Clin. 2007, 25, 303-317. [CrossRef]

118. Ramos, K.M.; Jiang, Y.; Svensson, C.I.; Calcutt, N.A. Pathogenesis of spinally mediated hyperalgesia in diabetes. Diabetes 2007, 56, 1569-1576. [CrossRef] [PubMed]

119. Goossens, G.H. The renin-angiotensin system in the pathophysiology of type 2 diabetes. Obes. Facts 2012, 5, 611-624. [CrossRef] [PubMed]

120. Miguel-Carrasco, J.L.; Zambrano, S.; Blanca, A.J.; Mate, A.; Vazquez, C.M. Captopril reduces cardiac inflammatory markers in spontaneously hypertensive rats by inactivation of nf-kb. J. Inflamm. 2010, 7, 21. [CrossRef]

121. David, J.A.; Rifkin, W.J.; Rabbani, P.S.; Ceradini, D.J. The nrf2/keap1/are pathway and oxidative stress as a therapeutic target in type ii diabetes mellitus. J. Diabetes Res. 2017, 2017, 4826724. [CrossRef] [PubMed]

122. Eguchi, K.; Nagai, R. Islet inflammation in type 2 diabetes and physiology. J. Clin. Investig. 2017, 127, 14-23. [CrossRef]

123. Uzar, E.; Alp, H.; Cevik, M.U.; Firat, U.; Evliyaoglu, O.; Tufek, A.; Altun, Y. Ellagic acid attenuates oxidative stress on brain and sciatic nerve and improves histopathology of brain in streptozotocin-induced diabetic rats. Neurol. Sci. 2012, 33, 567-574. [CrossRef] [PubMed]

124. Erel, O. A novel automated direct measurement method for total antioxidant capacity using a new generation, more stable abts radical cation. Clin. Biochem. 2004, 37, 277-285. [CrossRef] [PubMed]

125. Erel, O. A new automated colorimetric method for measuring total oxidant status. Clin. Biochem. 2005, 38, 1103-1111. [CrossRef]

126. Rauter, I.; Krauth, M.T.; Flicker, S.; Gieras, A.; Westritschnig, K.; Vrtala, S.; Balic, N.; Spitzauer, S.; Huss-Marp, J.; Brockow, K.; et al. Allergen cleavage by effector cell-derived proteases regulates allergic inflammation. FASEB J. 2006, 20, 967-969. [CrossRef] [PubMed]

127. Hofbauer, B.; Saluja, A.K.; Bhatia, M.; Frossard, J.L.; Lee, H.S.; Bhagat, L.; Steer, M.L. Effect of recombinant platelet-activating factor acetylhydrolase on two models of experimental acute pancreatitis. Gastroenterology 1998, 115, 1238-1247. [CrossRef]

128. Lambeth, J.D. Nox enzymes and the biology of reactive oxygen. Nat. Rev. Immunol. 2004, 4, 181-189. [CrossRef]

129. Bedard, K.; Krause, K.H. The nox family of ros-generating nadph oxidases: Physiology and pathophysiology. Physiol. Rev. 2007, 87, 245-313. [CrossRef]

130. Bennett, G.J.; Xie, Y.K. A peripheral mononeuropathy in rat that produces disorders of pain sensation like those seen in man. Pain 1988, 33, 87-107. [CrossRef]

131. Cao, H.; Zheng, J.W.; Li, J.J.; Meng, B.; Li, J.; Ge, R.S. Effects of curcumin on pain threshold and on the expression of nuclear factor kappa $b$ and cx3c receptor 1 after sciatic nerve chronic constrictive injury in rats. Chin. J. Integr. Med. 2014, 20, 850-856. [CrossRef] [PubMed]

132. Di, Y.X.; Hong, C.; Jun, L.; Renshan, G.; Qinquan, L. Curcumin attenuates mechanical and thermal hyperalgesia in chronic constrictive injury model of neuropathic pain. Pain 2014, 3, 59-69. [CrossRef]

133. Yu, X.; Cao, H. Curcumin attenuates the expression of nmdar-nr1 in chronic constructive injury model of neuropathic pain. Int. J. Pharmacol. Res. 2015, 5, 35.

134. Zhao, X.; Xu, Y.; Zhao, Q.; Chen, C.R.; Liu, A.M.; Huang, Z.L. Curcumin exerts antinociceptive effects in a mouse model of neuropathic pain: Descending monoamine system and opioid receptors are differentially involved. Neuropharmacology 2012, 62, 843-854. [CrossRef]

135. Zhu, X.; Li, Q.; Chang, R.; Yang, D.; Song, Z.; Guo, Q.; Huang, C. Curcumin alleviates neuropathic pain by inhibiting p300/cbp histone acetyltransferase activity-regulated expression of bdnf and cox-2 in a rat model. PLoS ONE 2014, 9, e91303. [CrossRef]

136. Jeon, Y.; Kim, C.-E.; Jung, D.; Kwak, K.; Park, S.; Lim, D.; Kim, S.; Baek, W. Curcumin could prevent the development of chronic neuropathic pain in rats with peripheral nerve injury. Curr. Ther. Res. Clin. Exp. 2013, 74, 1-4. [CrossRef] [PubMed]

137. Moini Zanjani, T.; Ameli, H.; Labibi, F.; Sedaghat, K.; Sabetkasaei, M. The attenuation of pain behavior and serum cox-2 concentration by curcumin in a rat model of neuropathic pain. Korean J. Pain 2014, 27, 246-252. [CrossRef] [PubMed]

138. Rajakariar, R.; Yaqoob, M.; Gilroy, D. Cox-2 in inflammation and resolution. Mol. Interv. 2006, 6, 199-207. [CrossRef] [PubMed]

139. Luo, C.; He, M.-1.; Bohlin, L. Is cox-2 a perpetrator or a protector? Selective cox-2 inhibitors remain controversial. Acta Pharmacol. Sin. 2005, 26, 926-933. [CrossRef] [PubMed]

140. Hinz, B.; Brune, K. Cyclooxygenase-2-10 years later. J. Pharmacol. Exp. Ther. 2002, 300, 367-375. [CrossRef]

141. Dover, A.R.; Hadoke, P.W.; Macdonald, L.J.; Miller, E.; Newby, D.E.; Walker, B.R. Intravascular glucocorticoid metabolism during inflammation and injury in mice. Endocrinology 2007, 148, 166-172. [CrossRef] [PubMed]

142. Wang, S.; Lim, G.; Zeng, Q.; Sung, B.; Yang, L.; Mao, J. Central glucocorticoid receptors modulate the expression and function of spinal nmda receptors after peripheral nerve injury. J. Neurosci. 2005, 25, 488-495. [CrossRef]

143. Tian, F.; Hu, X.Z.; Wu, X.; Jiang, H.; Pan, H.; Marini, A.M.; Lipsky, R.H. Dynamic chromatin remodeling events in hippocampal neurons are associated with nmda receptor-mediated activation of bdnf gene promoter 1. J. Neurochem. 2009, 109, 1375-1388. [CrossRef] [PubMed]

144. Ceyhan, D.; Kocman, A.E.; Yildirim, E.; Ozatik, O.; Aydin, S.; Kose, A. Comparison of the effects of curcumin, tramadol and surgical treatments on neuropathic pain induced by chronic constriction injury in rats. Turk. Neurosurg. 2018, 28, 288-295. [CrossRef] [PubMed] 
145. Mei, X.P.; Chen, L.; Wang, W.; Wu, D.; Wang, L.Y.; Zhang, T.; Zhang, H.; Xu, L.X.; Li, Y.Q. Combination of tramadol with minocycline exerted synergistic effects on a rat model of nerve injury-induced neuropathic pain. Neurosignals 2013, 21, 184-196. [CrossRef]

146. Sun, W.; Sun, C.; Lin, H.; Zhao, H.; Wang, J.; Ma, H.; Chen, B.; Xiao, Z.; Dai, J. The effect of collagen-binding ngf-beta on the promotion of sciatic nerve regeneration in a rat sciatic nerve crush injury model. Biomaterials 2009, 30, 4649-4656. [CrossRef]

147. Yin, Z.S.; Zhang, H.; Bo, W.; Gao, W. Erythropoietin promotes functional recovery and enhances nerve regeneration after peripheral nerve injury in rats. Am. J. Neuroradiol. 2010, 31, 509-515. [CrossRef]

148. Sun, W.; Sun, C.; Zhao, H.; Lin, H.; Han, Q.; Wang, J.; Ma, H.; Chen, B.; Xiao, Z.; Dai, J. Improvement of sciatic nerve regeneration using laminin-binding human ngf-beta. PLoS ONE 2009, 4, e6180. [CrossRef]

149. Robinson, L.R. Traumatic injury to peripheral nerves. Muscle Nerve 2000, 23, 863-873. [CrossRef]

150. Caillaud, M.; Chantemargue, B.; Richard, L.; Vignaud, L.; Favreau, F.; Faye, P.-A.; Vignoles, P.; Sturtz, F.; Trouillas, P.; Vallat, J.-M.; et al. Local low dose curcumin treatment improves functional recovery and remyelination in a rat model of sciatic nerve crush through inhibition of oxidative stress. Neuropharmacology 2018, 139, 98-116. [CrossRef] [PubMed]

151. Moharrami Kasmaie, F.; Jahromi, Z.; Gazor, R.; Zaminy, A. Comparison of melatonin and curcumin effect at the light and dark periods on regeneration of sciatic nerve crush injury in rats. EXCLI J. 2019, 18, 653-665. [PubMed]

152. Ma, J.; Liu, J.; Yu, H.; Wang, Q.; Chen, Y.; Xiang, L. Curcumin promotes nerve regeneration and functional recovery in rat model of nerve crush injury. Neurosci. Lett. 2013, 547, 26-31. [CrossRef] [PubMed]

153. Noorafshan, A.; Omidi, A.; Karbalay-Doust, S. Curcumin protects the dorsal root ganglion and sciatic nerve after crush in rat. Pathol. Res. Pract. 2011, 207, 577-582. [CrossRef] [PubMed]

154. Yuce, S. An experimental comparison of the effects of propolis, curcumin, and methylprednisolone on crush injuries of the sciatic nerve. Ann. Plast. Surg. 2015, 74, 684-692. [CrossRef]

155. Maurício, A.C. Peripheral Nerve Regeneration: From Surgery to New Therapeutic Approaches Including Biomaterials and Cell-Based Therapies Development; BoD-Books on Demand: Norderstedt, Germany, 2017.

156. Rateb, E.E.; Amin, S.N.; El-Tablawy, N.; Rashed, L.A.; El-Attar, S. Effect of melatonin supplemented at the light or dark period on recovery of sciatic nerve injury in rats. EXCLI J. 2017, 16, 138-150.

157. Gupta, J.; Qureshi, S. Potential benefits of methylcobalamin: A review. Austin J. Pharmacol. Ther. 2015, 3, 1076-1080.

158. Sang, Q.; Sun, D.; Chen, Z.; Zhao, W. Ngf and pi3k/akt signaling participate in the ventral motor neuronal protection of curcumin in sciatic nerve injury rat models. Biomed. Pharm. 2018, 103, 1146-1153. [CrossRef] [PubMed]

159. Liu, S.; Li, Q.; Zhang, M.-T.; Mao-Ying, Q.-L.; Hu, L.-Y.; Wu, G.-C.; Mi, W.-L.; Wang, Y.-Q. Curcumin ameliorates neuropathic pain by down-regulating spinal il-1 $\beta$ via suppressing astroglial nalp1 inflammasome and jak2-stat3 signalling. Sci. Rep. 2016, 6, 28956. [CrossRef] [PubMed]

160. Pastrana-Quintos, T.; Salgado-Moreno, G.; Pérez-Ramos, J.; Coen, A.; Godínez-Chaparro, B. Anti-allodynic effect induced by curcumin in neuropathic rat is mediated through the no-cyclic-GMP-ATP sensitive $\mathrm{K}^{+}$channels pathway. BMC Complement. Med. Ther. 2020, 20, 83. [CrossRef] [PubMed]

161. Lee, J.H.; Kim, Y.D.; Jung, H.C.; Cheong, Y.K. The effect of intrathecal curcumin on mechanical allodynia in rats after 15 spinal nerve ligation. Korean J. Anesthesiol. 2014, 67, S122-S123. [CrossRef] [PubMed]

162. Decosterd, I.; Woolf, C.J. Spared nerve injury: An animal model of persistent peripheral neuropathic pain. Pain 2000, 87, 149-158 [CrossRef]

163. Shields, S.D.; Eckert, W.A., 3rd; Basbaum, A.I. Spared nerve injury model of neuropathic pain in the mouse: A behavioral and anatomic analysis. J. Pain 2003, 4, 465-470. [CrossRef]

164. Ji, R.R.; Xu, Z.Z.; Gao, Y.J. Emerging targets in neuroinflammation-driven chronic pain. Nat. Rev. Drug Discov. 2014, 13, 533-548. [CrossRef] [PubMed]

165. Pillarisetti, S. Targeting interleukin-1 $\beta$ for pain. CNS Neurol. Disord. Drug Targets 2011, 10, 571-575. [CrossRef]

166. Kiso, T.; Watabiki, T.; Tsukamoto, M.; Okabe, M.; Kagami, M.; Nishimura, K.; Aoki, T.; Matsuoka, N. Pharmacological characterization and gene expression profiling of an 15/16 spinal nerve ligation model for neuropathic pain in mice. Neuroscience 2008, 153, 492-500. [CrossRef]

167. Woolf, C.J. Overcoming obstacles to developing new analgesics. Nat. Med. 2010, 16, 1241-1247. [CrossRef]

168. Apfelbaum, J.; Chen, C.; Mehta, S.; Gan, T. Postoperative pain experience: Results from a national survey suggest postoperative pain continues to be undermanaged. Anesth. Analg. 2003, 97, 534-540. [CrossRef]

169. Phillips, C.; Gelesko, S.; Proffit, W.R.; White, R.P., Jr. Recovery after third-molar surgery: The effects of age and sex. Am. J. Orthod. Dentofac. Orthop. 2010, 138, 700.e1-700.e8. [CrossRef] [PubMed]

170. Zhu, Q.; Sun, Y.; Yun, X.; Ou, Y.; Zhang, W.; Li, J.X. Antinociceptive effects of curcumin in a rat model of postoperative pain. Sci. Rep. 2014, 4, 4932. [CrossRef] [PubMed]

171. Sahbaie, P.; Sun, Y.; Liang, D.Y.; Shi, X.Y.; Clark, J.D. Curcumin treatment attenuates pain and enhances functional recovery after incision. Anesth. Analg. 2014, 118, 1336-1344. [CrossRef] [PubMed]

172. Lantero, A.; Tramullas, M.; Diaz, A.; Hurle, M.A. Transforming growth factor-beta in normal nociceptive processing and pathological pain models. Mol. Neurobiol. 2012, 45, 76-86. [CrossRef] [PubMed] 
173. Ju, J.; Shin, J.; Yoon, J.; Yin, M.; Yoon, M. Differential expression of spinal $\gamma$-aminobutyric acid and opioid receptors modulates the analgesic effects of intrathecal curcumin on postoperative/inflammatory pain in rats. Anesth. Pain Med. 2018, 13, 82-92. [CrossRef]

174. Ma, P.; Tumin, D.; Cismowski, M.; Tobias, J.D.; Gomez, D.; McConnell, P.; Naguib, A.; Yates, A.R.; Winch, P. Effects of preoperative curcumin on the inflammatory response during mechanical circulatory support: A porcine model. Cardiol. Res. 2018, 9, 7-10. [CrossRef] [PubMed]

175. Bulboaca, A.E.; Bolboaca, S.D.; Stanescu, I.C.; Sfrangeu, C.A.; Bulboaca, A.C. Preemptive analgesic and antioxidative effect of curcumin for experimental migraine. BioMed Res. Int. 2017, 2017, 4754701. [CrossRef]

176. Nurullahoglu, K.E.; Okudan, N.; Belviranli, M.; Oz, M. The comparison of preemptive analgesic effects of curcumin and diclofenac. Bratisl. Lekárske Listy 2014, 115, 757-760. [CrossRef] [PubMed]

177. Woolf, C.J.; Chong, M.S. Preemptive analgesia-Treating postoperative pain by preventing the establishment of central sensitization. Anesth. Analg. 1993, 77, 362-379. [CrossRef] [PubMed]

178. Katz, J. Pre-emptive analgesia: Evidence, current status and future directions. Eur. J. Anaesthesiol. Suppl. 1995, 10, 8-13. [PubMed]

179. Kissin, I. Preemptive analgesia: Problems with assessment of clinical significance. Methods Mol. Biol. 2010, 617, 475-482. [PubMed]

180. Van der Marel, C.D.; Anderson, B.J.; Romsing, J.; Jacqz-Aigrain, E.; Tibboel, D. Diclofenac and metabolite pharmacokinetics in children. Paediatr. Anaesth. 2004, 14, 443-451. [CrossRef]

181. Buggy, D.J.; Wall, C.; Carton, E.G. Preoperative or postoperative diclofenac for laparoscopic tubal ligation. Br. J. Anaesth. 1994, 73, 767-770. [CrossRef]

182. Gillberg, L.E.; Harsten, A.S.; Stahl, L.B. Preoperative diclofenac sodium reduces post-laparoscopy pain. Can. J. Anaesth. 1993, 40 Pt 1, 406-408. [CrossRef]

183. Evers, S.; Afra, J.; Frese, A.; Goadsby, P.J.; Linde, M.; May, A.; Sandor, P.S.; European Federation of Neurological Societies. EFNS guideline on the drug treatment of migraine-Revised report of an EFNS task force. Eur. J. Neurol. 2009, 16, 968-981. [CrossRef]

184. Freitag, F.G. The cycle of migraine: Patients' quality of life during and between migraine attacks. Clin. Ther. 2007, 29, 939-949. [CrossRef] [PubMed]

185. Saxena, P.R.; Den Boer, M.O. Pharmacology of antimigraine drugs. J. Neurol. 1991, 238, S28-S35. [CrossRef] [PubMed]

186. Antony, B.; Merina, B.; Iyer, V.S.; Judy, N.; Lennertz, K.; Joyal, S. A pilot cross-over study to evaluate human oral bioavailability of bcm-95cg (biocurcumax), a novel bioenhanced preparation of curcumin. Indian J. Pharm. Sci. 2008, 70, 445-449. [CrossRef] [PubMed]

187. Sunagawa, Y.; Hirano, S.; Katanasaka, Y.; Miyazaki, Y.; Funamoto, M.; Okamura, N.; Hojo, Y.; Suzuki, H.; Doi, O.; Yokoji, T.; et al Colloidal submicron-particle curcumin exhibits high absorption efficiency-a double-blind, 3-way crossover study. J. Nutr. Sci. Vitaminol. 2015, 61, 37-44. [CrossRef] [PubMed]

188. Jager, R.; Lowery, R.P.; Calvanese, A.V.; Joy, J.M.; Purpura, M.; Wilson, J.M. Comparative absorption of curcumin formulations. Nutr. J. 2014, 13, 11. [CrossRef]

189. Shoba, G.; Joy, D.; Joseph, T.; Majeed, M.; Rajendran, R.; Srinivas, P.S. Influence of piperine on the pharmacokinetics of curcumin in animals and human volunteers. Planta Med. 1998, 64, 353-356. [CrossRef]

190. Purpura, M.; Lowery, R.P.; Wilson, J.M.; Mannan, H.; Munch, G.; Razmovski-Naumovski, V. Analysis of different innovative formulations of curcumin for improved relative oral bioavailability in human subjects. Eur. J. Nutr. 2018, 57, 929-938. [CrossRef] [PubMed]

191. Chen, Q.; Prior, M.; Dargusch, R.; Roberts, A.; Riek, R.; Eichmann, C.; Chiruta, C.; Akaishi, T.; Abe, K.; Maher, P.; et al. A novel neurotrophic drug for cognitive enhancement and alzheimer's disease. PLoS ONE 2011, 6, e27865. [CrossRef]

192. Prior, M.; Goldberg, J.; Chiruta, C.; Farrokhi, C.; Kopynets, M.; Roberts, A.J.; Schubert, D. Selecting for neurogenic potential as an alternative for alzheimer's disease drug discovery. Alzheimers Dement. J. Alzheimers Assoc. 2016, 12, 678-686. [CrossRef]

193. Calcutt, N.A.; Smith, D.R.; Frizzi, K.; Sabbir, M.G.; Chowdhury, S.K.R.; Mixcoatl-Zecuatl, T.; Saleh, A.; Muttalib, N.; Van der Ploeg, R.; Ochoa, J.; et al. Selective antagonism of muscarinic receptors is neuroprotective in peripheral neuropathy. J. Clin. Investig. 2017, 127, 608-622. [CrossRef]

194. Roy Chowdhury, S.K.; Smith, D.R.; Saleh, A.; Schapansky, J.; Marquez, A.; Gomes, S.; Akude, E.; Morrow, D.; Calcutt, N.A.; Fernyhough, P. Impaired adenosine monophosphate-activated protein kinase signalling in dorsal root ganglia neurons is linked to mitochondrial dysfunction and peripheral neuropathy in diabetes. Brain J. Neurol. 2012, 135 Pt 6, 1751-1766. [CrossRef]

195. Katagiri, A.; Shinoda, M.; Honda, K.; Toyofuku, A.; Sessle, B.J.; Iwata, K. Satellite glial cell p2y12 receptor in the trigeminal ganglion is involved in lingual neuropathic pain mechanisms in rats. Mol. Pain 2012, 8, 23. [CrossRef] [PubMed]

196. Kobayashi, K.; Yamanaka, H.; Noguchi, K. Expression of atp receptors in the rat dorsal root ganglion and spinal cord. Anat. Sci. Int. 2013, 88, 10-16. [CrossRef] [PubMed]

197. Burnstock, G. Purinergic mechanisms and pain-an update. Eur. J. Pharm. 2013, 716, 24-40. [CrossRef] [PubMed]

198. Magni, G.; Ceruti, S. P2y purinergic receptors: New targets for analgesic and antimigraine drugs. Biochem. Pharm. 2013, 85, 466-477. [CrossRef] [PubMed]

199. Horvath, G.; Goloncser, F.; Csolle, C.; Kiraly, K.; Ando, R.D.; Baranyi, M.; Kovanyi, B.; Mate, Z.; Hoffmann, K.; Algaier, I.; et al. Central p2y12 receptor blockade alleviates inflammatory and neuropathic pain and cytokine production in rodents. Neurobiol. Dis. 2014, 70, 162-178. [CrossRef] [PubMed] 
200. Chandran, B.; Goel, A. A randomized, pilot study to assess the efficacy and safety of curcumin in patients with active rheumatoid arthritis. Phytother. Res. 2012, 26, 1719-1725. [CrossRef] [PubMed]

201. Belcaro, G.; Cesarone, M.R.; Dugall, M.; Pellegrini, L.; Ledda, A.; Grossi, M.G.; Togni, S.; Appendino, G. Efficacy and safety of meriva(r), a curcumin-phosphatidylcholine complex, during extended administration in osteoarthritis patients. Altern. Med. Rev. 2010, 15, 337-344.

202. Nakagawa, Y.; Mukai, S.; Yamada, S.; Matsuoka, M.; Tarumi, E.; Hashimoto, T.; Tamura, C.; Imaizumi, A.; Nishihira, J.; Nakamura, T. Short-term effects of highly-bioavailable curcumin for treating knee osteoarthritis: A randomized, double-blind, placebo-controlled prospective study. J. Orthop. Sci. 2014, 19, 933-939. [CrossRef]

203. Haroyan, A.; Mukuchyan, V.; Mkrtchyan, N.; Minasyan, N.; Gasparyan, S.; Sargsyan, A.; Narimanyan, M.; Hovhannisyan, A. Efficacy and safety of curcumin and its combination with boswellic acid in osteoarthritis: A comparative, randomized, double-blind, placebo-controlled study. BMC Complement. Altern. Med. 2018, 18, 7. [CrossRef]

204. Shep, D.; Khanwelkar, C.; Gade, P.; Karad, S. Safety and efficacy of curcumin versus diclofenac in knee osteoarthritis: A randomized open-label parallel-arm study. Trials 2019, 20, 214. [CrossRef]

205. Sterzi, S.; Giordani, L.; Morrone, M.; Lena, E.; Magrone, G.; Scarpini, C.; Milighetti, S.; Pellicciari, L.; Bravi, M.; Panni, I.; et al. The efficacy and safety of a combination of glucosamine hydrochloride, chondroitin sulfate and bio-curcumin with exercise in the treatment of knee osteoarthritis: A randomized, double-blind, placebo-controlled study. Eur. J. Phys. Rehabil. Med. 2016, 52, 321-330.

206. Pinsornsak, P.; Niempoog, S. The efficacy of curcuma longa l. Extract as an adjuvant therapy in primary knee osteoarthritis: A randomized control trial. J. Med. Assoc. Thail. Chotmaihet Thangphaet 2012, 95 (Suppl. 1), S51-S58.

207. Madhu, K.; Chanda, K.; Saji, M.J. Safety and efficacy of curcuma longa extract in the treatment of painful knee osteoarthritis: A randomized placebo-controlled trial. Inflammopharmacology 2013, 21, 129-136. [CrossRef] [PubMed]

208. Henrotin, Y.; Gharbi, M.; Dierckxsens, Y.; Priem, F.; Marty, M.; Seidel, L.; Albert, A.; Heuse, E.; Bonnet, V.; Castermans, C. Decrease of a specific biomarker of collagen degradation in osteoarthritis, coll2-1, by treatment with highly bioavailable curcumin during an exploratory clinical trial. BMC Complement. Altern. Med. 2014, 14, 159. [CrossRef] [PubMed]

209. Agarwal, K.A.; Tripathi, C.D.; Agarwal, B.B.; Saluja, S. Efficacy of turmeric (curcumin) in pain and postoperative fatigue after laparoscopic cholecystectomy: A double-blind, randomized placebo-controlled study. Surg. Endosc. 2011, 25, 3805-3810. [CrossRef]

210. Anil, A.; Gujjari, S.K.; Venkatesh, M.P. Evaluation of a curcumin-containing mucoadhesive film for periodontal postsurgical pain control. J. Indian Soc. Periodontol. 2019, 23, 461-468. [PubMed]

211. Asadi, S.; Gholami, M.S.; Siassi, F.; Qorbani, M.; Khamoshian, K.; Sotoudeh, G. Nano curcumin supplementation reduced the severity of diabetic sensorimotor polyneuropathy in patients with type 2 diabetes mellitus: A randomized double-blind placebo-controlled clinical trial. Complement. Med. 2019, 43, 253-260. [CrossRef] [PubMed]

212. Belcaro, G.; Hosoi, M.; Pellegrini, L.; Appendino, G.; Ippolito, E.; Ricci, A.; Ledda, A.; Dugall, M.; Cesarone, M.R.; Maione, C.; et al A controlled study of a lecithinized delivery system of curcumin (meriva(r)) to alleviate the adverse effects of cancer treatment. Phytother. Res. 2014, 28, 444-450. [CrossRef] [PubMed]

213. Maulina, T.; Diana, H.; Cahyanto, A.; Amaliya, A. The efficacy of curcumin in managing acute inflammation pain on the post-surgical removal of impacted third molars patients: A randomised controlled trial. J. Oral Rehabil. 2018, 45, 677-683. [CrossRef]

214. Phoolcharoen, N.; Oranratanaphan, S.; Ariyasriwatana, C.; Worasethsin, P. Efficacy of curcuminoids for reducing postoperative pain after laparoscopic gynecologic surgery: A pilot randomized trial. J. Complement. Integr. Med. 2019, 16. [CrossRef]

215. Di Pierro, F.; Settembre, R. Safety and efficacy of an add-on therapy with curcumin phytosome and piperine and/or lipoic acid in subjects with a diagnosis of peripheral neuropathy treated with dexibuprofen. J. Pain Res. 2013, 6, 497-503. [CrossRef] [PubMed]

216. Dyck, P.J.; Davies, J.L.; Litchy, W.J.; O’Brien, P.C. Longitudinal assessment of diabetic polyneuropathy using a composite score in the rochester diabetic neuropathy study cohort. Neurology 1997, 49, 229-239. [CrossRef]

217. Davies, M.; Brophy, S.; Williams, R.; Taylor, A. The prevalence, severity, and impact of painful diabetic peripheral neuropathy in type 2 diabetes. Diabetes Care 2006, 29, 1518-1522. [CrossRef] [PubMed]

218. Tesfaye, S.; Stevens, L.K.; Stephenson, J.M.; Fuller, J.H.; Plater, M.; Ionescu-Tirgoviste, C.; Nuber, A.; Pozza, G.; Ward, J.D. Prevalence of diabetic peripheral neuropathy and its relation to glycaemic control and potential risk factors: The eurodiab iddm complications study. Diabetologia 1996, 39, 1377-1384. [CrossRef] [PubMed]

219. Gupta, S.C.; Patchva, S.; Koh, W.; Aggarwal, B.B. Discovery of curcumin, a component of golden spice, and its miraculous biological activities. Clin. Exp. Pharm. Physiol. 2012, 39, 283-299. [CrossRef] [PubMed]

220. Or, S.; Bozkurt, A. Analgesic effect of aspirin, mefenamic acid and their combination in post-operative oral surgery pain. J. Int Med. Res. 1988, 16, 167-172. [CrossRef]

221. Harrison, R.F.; Brennan, M. Comparison of two formulations of lignocaine spray with mefenamic acid in the relief of postepisiotomy pain: A placebo-controlled study. Curr. Med. Res. Opin. 1987, 10, 375-379. [CrossRef] [PubMed]

222. Michelet, D.; Andreu-Gallien, J.; Bensalah, T.; Hilly, J.; Wood, C.; Nivoche, Y.; Mantz, J.; Dahmani, S. A meta-analysis of the use of nonsteroidal antiinflammatory drugs for pediatric postoperative pain. Anesth. Analg. 2012, 114, 393-406. [CrossRef] [PubMed] 
223. Wang, X.-M.; Hamza, M.; Wu, T.-X.; Dionne, R.A. Upregulation of il-6, il-8 and ccl2 gene expression after acute inflammation: Correlation to clinical pain. Pain 2009, 142, 275-283. [CrossRef]

224. Bouffi, C.; Bony, C.; Courties, G.; Jorgensen, C.; Noël, D. Il-6-dependent pge2 secretion by mesenchymal stem cells inhibits local inflammation in experimental arthritis. PLoS ONE 2010, 5, e14247. [CrossRef] [PubMed] 